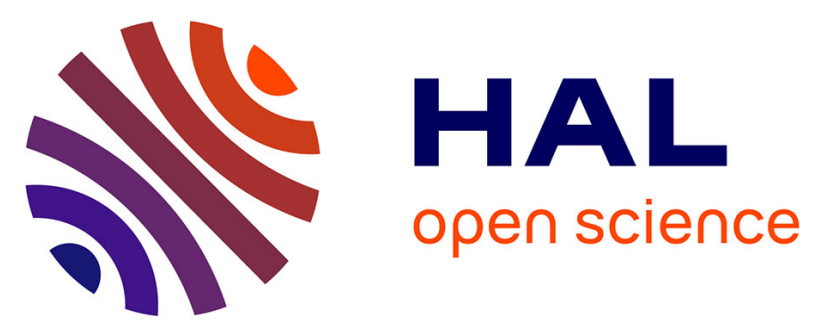

\title{
Influence of forest tree species composition on bryophytic diversity in mixed and pure pine (Pinus sylvestris L.) and oak (Quercus petraea (Matt.) Liebl.) stands
}

Marion Gosselin, D. Fourcin, Yann Dumas, Frédéric Gosselin, Nathalie Korboulewsky, M. Toïgo, P. Vallet

\section{To cite this version:}

Marion Gosselin, D. Fourcin, Yann Dumas, Frédéric Gosselin, Nathalie Korboulewsky, et al.. Influence of forest tree species composition on bryophytic diversity in mixed and pure pine (Pinus sylvestris L.) and oak (Quercus petraea (Matt.) Liebl.) stands. Forest Ecology and Management, 2017, 406, pp.318-329. 10.1016/j.foreco.2017.09.067 . hal-02499868

\section{HAL Id: hal-02499868 \\ https://hal.science/hal-02499868}

Submitted on 5 Mar 2020

HAL is a multi-disciplinary open access archive for the deposit and dissemination of scientific research documents, whether they are published or not. The documents may come from teaching and research institutions in France or abroad, or from public or private research centers.
L'archive ouverte pluridisciplinaire HAL, est destinée au dépôt et à la diffusion de documents scientifiques de niveau recherche, publiés ou non, émanant des établissements d'enseignement et de recherche français ou étrangers, des laboratoires publics ou privés. 
1 Influence of forest tree species

2 composition on bryophytic diversity in

3 mixed and pure pine (Pinus sylvestris L.)

4 and oak (Quercus petraea (Matt.) Liebl.)

5 stands

Marion Gosselin, Deki Fourcin, Yann Dumas, Frédéric Gosselin, Nathalie Korboulewsky, Maude Toïgo, Patrick Vallet

IRSTEA, UR EFNO Ecosystèmes Forestiers, Centre de Nogent-sur-Vernisson, Domaine des Barres, F-45290 Nogent-sur-Vernisson, France

Corresponding author: Marion Gosselin

Address: IRSTEA, UR EFNO Ecosystèmes Forestiers, Centre de Nogent-sur-Vernisson, Domaine des Barres, F-45290 Nogent-sur-Vernisson, France

E-mail address: marion.gosselin@irstea.fr

Highlights

- Bryophyte diversity on and around tree trunks was higher for oak than for pine.

- Mixed stands enhanced bryophyte diversity for pine trees.

- At the plot level, mixed stands and pure oak stands had similar bryophyte richness.

- Nevertheless, some species were more likely to be found on pines.

- Exploratory models revealed strong effects for basal area and water supply chemistry.

Keywords

Forest biodiversity; bryophyte; mixed woods; tree composition; Oak (Quercus petraea); Scots pine (Pinus sylvestris)

\section{Abstract}

The effects of mixed stands on biodiversity are increasingly being studied since they are supposed to offer higher habitat heterogeneity. Nevertheless, for tree-associated diversity, including epiphytes and terricolous species near tree trunks, few studies exist, and still fewer compare mixed stands with each corresponding pure tree species stand. We evaluated and quantified the influence of forest composition on tree-associated bryophyte diversity (species richness, abundance, composition) in mixed and pure oak-pine stands in a French lowland forest. The main explanatory variables for bryophyte diversity at tree-level were the identity of the phorophyte tree species and the mixture type (pure versus mixed). At the plot level, the main explanatory variable was the stand type (pure oak, pure pine and mixed). We also explored the role of other variables including the chemistry of the bryophyte 
substrates (soil, bark) and water supply (stemflow, throughfall), as well as stand abundance variables (basal area, interfering plant cover). We analyzed data with Generalized Linear Models under Bayesian statistics, to take into account the spatial autocorrelation between plots and any under- or over-dispersion of our data. At the tree-level, bryophyte richness and abundance were higher on oak than on pine. Pine bryophyte richness was higher in mixed compared to pure stands, whereas for oak, mixed stands did not enhance bryophyte richness. At the plot level, mixed stands hosted bryophyte communities of similar richness to those in pure oak stands, whereas pure pine stands were clearly poorer. Our exploratory models suggested strong effects of water supply chemistry (stemflow and throughfall $\mathrm{pH}$ or conductivity) and basal area; the latter had a strong quadratic effect on epiphytic richness at the plot level. In terms of composition, three species were more likely to be found on pine phorophytes, seven species clearly occurred more frequently on oaks. Some species were more likely to be associated to pine in mixed than in pure stands, and one species was found more often under pines in pure stands. Therefore, bryophyte diversity at the landscape level should benefit from the simultaneous presence of the three stand composition types - pure oak, pure pine and mixed stands.

\section{Abbreviations}

SR: species richness; epiph: epiphytic species; AB: abundance; TF: throughfall; SF: stemflow; G: basal area; ground: ground-dwelling species; glob: both epiphytic and ground-dwelling species; OM: organic mineral horizon; Rec_interf_Glob: cover percentage of interfering plants inside a ring 1 meter in width traced around the tree.

\section{Introduction}

Mixed-species forest stands are increasingly being studied because of their potential benefits in reconciling ecological and productivity goals, as compared to monoculture stands. These benefits include biodiversity enhancement (Barbier et al., 2008; Cannell et al., 1992; Cavard et al., 2011b; Sobek et al., 2010), improved growth rates of stands (del Rio and Sterba, 2009; Pérot and Picard, 2012; Pretzsch, 2003; Vallet and Pérot, 2011), more efficient water consumption (Lubbe et al., 2016), better soil properties (Brandtberg et al., 2000; Brandtberg and Lundkvist, 2004; Vaychis and Danusyavichus, 1978), reduced biotic pathogen damage ( Jactel et al., 2005; Jactel and Brockerhoff, 2007; Koricheva et al., 2006; Lygis et al., 2004; Watt, 1992) and better tree growth compensation following insect damage (Perot et al., 2013).

Nevertheless, mixed stands are not always better than pure ones with regard to these criteria since other variables also play a role, like site conditions (Toïgo et al., 2015; Zilliox and Gosselin, 2014), tree species composition of the mixture (Parrotta, 1999; Simmons and Buckley, 1992) and, as far as biodiversity is concerned, the taxonomic or ecological groups under study (see Migge et al. (1998) for oribatid mite diversity, Scheu et al. (2003) for soil microfauna biomass, Smith (1992) for bird communities, Oxbrough et al.(2012) for arthropod fauna, Barbier et al. (2009b) and Zilliox and Gosselin (2014) for vascular plants, Cavard et al. (2011a) for vascular plants and ground bryophyte understory biomass, Cavard et al. (2011b) for soil organisms). Further studies are needed to better assess the effects of different types of tree species mixtures on biodiversity, even for mixtures of widespread species like sessile oak or Scots pine (Barsoum et al., 2014).

Mixing tree species increases the structural heterogeneity of the stand and habitat diversity, as shown by Cavard et al.'s review (2011b), and allows more plant, animal or fungal species to colonize the stand. The diversity of epiphyte communities in particular could be enhanced in mixed stands, since different tree species provide different habitat substrates, through their differences in bark texture and chemical properties (Barkman, 1958). Since these differences in bark chemical properties 
also influence soil acidity and nutrient contents in the vicinity of the trunk (Gustafsson and Eriksson, 1995; Chang and Matzner, 2000b), mixed stands may also enhance habitat diversity for grounddwelling species around the trunk.

Bryophytes are of interest for studying the effect of mixed stands on biodiversity precisely because they include both epiphytes and ground dwelling species near trunks, which we will designate as tree-associated bryophytes. Epiphytic, terricolous and epixylic cryptogams are an important component of overall forest biodiversity; their richness is greater than that of vascular plants in many forest types (Kriebitzsch et al., 2013). In addition, they contribute to overall biodiversity as primary producers and serve as food resources and habitat for mammals (Virtanen et al., 2000), molluscs, insects like the Byrrhidae, and tardigrads who live and feed essentially in mosses.

Overall bryophyte diversity on a local scale is affected both by the regional macroclimate and by the microclimate and other local variables (Raabe et al., 2010), among which the composition of the stand. Indeed, as far as tree-associated bryophytes are concerned, bryophyte diversity may be influenced by both phorophyte and overall stand characteristics. Concerning phorophyte characteristics, tree-associated bryophyte diversity is firstly explained by substrate structure and chemistry (Cleavitt et al., 2009), light (Aude and Poulsen, 2000; Tinya et al., 2009) and wind and precipitation exposure; and secondly, by the phorophyte species (Cleavitt et al., 2009). Although epiphytic bryophytes are not host-tree-specific - each bryophyte species can be found on various host-tree species (Bates and Brown, 1981; Cleavitt et al., 2009; Gonzalez-Mancebo et al., 2003), bryophyte community composition can significantly differ among host tree species in mixed stands (Odor et al., 2013; McGee and Kimmerer, 2002), depending on the structural and chemical characteristics of the substrate. In particular, bryophytes are known to be sensitive to the $\mathrm{pH}$ of their substrate - whether bark, rock or soil (Barkman, 1958; Bates and Brown, 1981; Bates, 1992; Fritz and Heilmann-Clausen, 2010) as well as to the $\mathrm{pH}$ and nutrient content of their water supply. Some authors have also used conductivity of water supplies or soil solutes as a proxy for their nutrient content (e.g. Sutinen et al., 2002). In forest stands, bryophyte water supplies consist of either throughfall, for ground species, or stemflow for trunk epiphytes: throughfall is the rainwater that falls to the ground through the canopy, and stemflow is rainwater that runs down the trunk of the tree (Barkman, 1958; Bates and Brown, 1981; Farmer et al., 1991; Leith et al., 2008; Nagano, 1972). Stemflow acidity can also affect the ground assemblages (vascular flora or bryophytes) at the base of the trunks, with more acidic indicator species adjacent to the tree (Neite and Wittig, 1985; Wittig and Neite, 1985). Indeed, Beniamino et al. (1991), Chang and Matzner (2000b) and Vellak et al. (2003) studied mean stemflow $\mathrm{pH}$ for different tree species and found that the acidic effects of stemflow decrease with distance from the tree. Among overall stand characteristics, stand density and cover of interfering plants (i.e. competing and covering vascular plants like Pteridium aquilinum (L.) Kuhn, Molinia caerulea (L.) Moench or Calluna vulgaris (L.) Hull (Dumas, 2006)) may also affect both ground-dwelling and epiphytic bryophytes because they are related to light and substrate availability: the higher the stand density or the interfering plant cover, the less light reaches the forest floor; smaller trunk diameters and low density may limit available habitats for epiphytes. In addition, increasing diameter is known to be positively correlated with epiphytic bryophyte richness (Gustafsson and Eriksson, 1995 or McGee and Kimmerer, 2002 cited by Marialigeti et al., 2009). 
publications have been specifically designed to compare this bryophyte diversity on individual tree species between pure and mixed stands. They indicate that epiphytic bryophyte diversity was higher in mixed stands at both tree and plot levels than in at least one corresponding pure stand, most often the coniferous one (Cleavitt et al. (2009) in mixed maple - spruce stands, Kiraly and Odor (2010) in Hungarian oak and pine forests, Felton et al. (2010) for spruce and birch). For ground bryophytes, Marialigeti et al. (2009) found that the presence of oak in a pine forest had a positive effect on the diversity of forest floor bryophytes at the stand level.

In this study, we investigated the effects of stand composition on the richness, abundance and composition of tree-associated bryophyte assemblages, i.e. epiphytic bryophytes at the trunk base and ground bryophytes in the trunk vicinity. We compared pure oak and pine stands with mixed oakpine stands in a lowland temperate forest with homogeneous acidic site conditions.

We addressed hypotheses for bryophyte diversity at both tree and plot level. The sampling design was balanced to assess tree species and stand composition effects, according to the following main hypotheses (see Table SM1):

$\mathrm{H} 1$ - tree-level bryophyte diversity (species richness and abundance) will be higher on oak than on pine and bryophyte species composition will differ between oak and pine (Barkman, 1958; Kiraly and Odor, 2010);

$\mathrm{H} 2$ - for a given phorophyte-species, tree-level bryophyte diversity (richness, abundance and composition) will differ between pure and mixed stands (Cleavitt et al., 2009; Kiraly et al., 2013);

H3 - plot level bryophyte diversity (richness and abundance) will be higher in mixed stands than in pure ones and bryophyte composition will differ between pure and mixed stands (Cavard et al., 2011b; Cleavitt et al., 2009; Kiraly and Odor, 2010).

For exploratory purposes and to further reflect on the mechanisms involved, we also checked if other variables such as the physical and chemical characteristics of the substrates (soil or bark) or the water supplies (throughfall or stemflow) had an effect (see Table SM1 - exploratory hypothesis H4). In addition to simple tree species identity and the interactive "species identity $\mathrm{x}$ stand composition type", we also investigated other stand variables (tree density, interfering plant cover) which might contribute to differences in bryophyte diversity (see Table SM1 - exploratory hypotheses H5 and H6).

We mainly stressed management-related variables (stand composition, tree density) in order to help translate results for forest managers paying attention to biodiversity conservation.

\section{Materials and methods}

\section{Study area}

The study was carried out in the National Forest of Orléans in central France. This temperate lowland forest stretches over $60 \mathrm{~km}$ to the North of the Loire river $\left(2^{\circ} 29^{\prime} \mathrm{E} ; 47^{\circ} 49^{\prime} \mathrm{N}\right)$ and covers around 35,000 hectares. The elevation is between 107 and 174 meters above sea level. The dominant tree species are sessile oak (Quercus petraea Liebl.) and Scot's pine (Pinus sylvestris L.). The climate is temperate continental with an oceanic influence. Mean annual temperature is about $11.3^{\circ} \mathrm{C}$, with an average minimum temperature of $0.7^{\circ} \mathrm{C}$ in February and an average maximum temperature of $25^{\circ} \mathrm{C}$ in July. The mean annual rainfall is $740 \mathrm{~mm}$ (1981-2010 data from the weather station at Nogent-sur- 
Vernisson, France, about $20 \mathrm{~km}$ east of the study area). Soils are relatively poor and acidic with a sandy upper layer on a clayey stratum; temporary waterlogging occurs in winter (planosol).

\section{Study design and bryophyte sampling}

Our sampling design was balanced according to the two main explanatory variables: tree species (oak, pine) and mixture type (pure or mixed). We selected 21 plots, corresponding to seven repetitions for each level of the combined factors (pure oak, pure pine, mixed oak-pine) - see Supplementary Material, Figure SM 1. All the plots belonged to a restricted range of similar site conditions and were located in even-aged stands managed by the French National Forest Office. Each plot was circular with a radius of 15 meters. Plots were split into three equal parts (delimited by the directions 0, 133 and 167 grades) and the largest tree of the given study species (oak and/or pine) in each part was selected to record bryophytes. We selected the largest trees to better estimate potential bryophyte richness, which is known to increase with tree diameter. Thus, we collected data on three trees per species and per plot, leading to a total of 84 trees (21 oaks in pure stands, 21 pines in pure stands, 21 oaks and 21 pines in mixed stands).

Data were collected between October and November, 2012. The bryophyte inventory was carried out at the tree level. Epiphytic bryophytes were recorded on the entire trunk from its base up to a height of 2 meters. We listed all bryophyte species present and assessed their abundance in cover classes. Ground bryophytes were recorded on six $50-b y-50 \mathrm{~cm}^{2}$ quadrats. These quadrats were located in three directions (azimuth 90, 210 and 330 degrees from magnetic North) around each phorophyte and were centered at two distances from the trunk $(25$ and $75 \mathrm{~cm}$ ). For each distance from a trunk, data were combined, giving us separate composite records for bryophyte species at 25 $\mathrm{cm}$ and $75 \mathrm{~cm}$ from the tree. An additional composite record for all under-tree ground species was obtained by combining the data from all six quadrats. We listed all bryophyte species present and assessed their total abundance (estimated in $\mathrm{cm}^{2}$ ).

Bryophytes were identified at species level, either in the field when possible or in the laboratory on collected samples, if necessary. Nomenclature follows the list established by Gargominy et al. (2015). It was not possible to identify Ulota at the species level in the absence of a capsule and in this case, they were recorded at the genus level as Ulota sp.

For each phorophyte, the final bryophyte data set included data of species richness (number of species on trunks or on soil), ground species abundance (cover in $\mathrm{cm}^{2}$, which cannot exceed 15,000 $\mathrm{cm}^{2}$ for any given tree), epiphyte species abundance (cover classes ranked in increasing order) and species binomial presence data. Data were calculated either at tree or plot level. To obtain plot level data, we had an unbalanced sampling effort between pure and mixed stands - three trees in pure stands and six trees in mixed stands. We therefore randomly selected three trees in each of the seven mixed-stand plots - forcing a selection of either two oaks and one pine or one oak and two pines; we then calculated the plot level data on the basis of these three randomly selected trees and used the three remaining trees to build seven "additional" mixed stand plots for which we also calculated the plot level data. We thus obtained a dataset of 28 plots: seven pure oak stands, seven pure pine stands and 14 mixed stands. 


\section{Environmental data}

In addition to the main variables (tree species and stand composition), we collected data for trunk diameter and inclination, stand density (basal area in $\mathrm{m}^{2}$ ha ${ }^{-1}$ for trees with dbh greater than $7.5 \mathrm{~cm}$ ), chemical characteristics of bryophyte substrate and water supply in October, 2012 and February, 2013. For the substrate and water supply, soil and throughfall were used in the analysis of forest floor species; whereas bark and stemflow were related to epiphytic bryophyte species.

We attributed an estimated cover percentage to interfering plant cover present under breast height in two concentric $50 \mathrm{~cm}$-wide rings around each tree, centered 25 and $75 \mathrm{~cm}$ away from the trunk. Additionally, we estimated the global interfering plant cover percentage within a $1 \mathrm{~m}$-radius circle around the tree.

A $2.5 \mathrm{~cm}$-high soil coring ring was used to collect samples of first, the fragmented organic (OF) surface horizon, then the underlying organo-mineral $(A)$ horizon at the base of each sampling tree. Samples were taken at 25 and $75 \mathrm{~cm}$ from the trunk in three directions (at the center of each ground bryophyte sampling quadrat). For each horizon, we combined the three samples to create two composite soil samples, one for each distance from the tree. Thus, we obtained four soil samples per sampling tree (one surface horizon and one organo-mineral horizon for each distance from the trunk).

Measurements of soil $\mathrm{pH}$ and conductivity were carried out in the laboratory according to the ISO 10390 norm (AFNOR, 1996).

Bark outer surface was collected on $4 \mathrm{~cm}^{2}$ from the West side of each tree at $1.10 \mathrm{~m}$ high, with a minimum amount of lichen. Samples were air dried, broken into small pieces, then $0.4 \mathrm{~g}$ was added to $4 \mathrm{ml}$ of demineralized water. The sample was left to soak for one hour before reading the $\mathrm{pH}$ (Eutech pH 6+ Meter). A further $15 \mathrm{ml}$ of demineralized water were added to measure the conductivity (Eutech Cond 6+).

Two series of water samples were collected for throughfall and stemflow pH and conductivity measurements (ISO 10523 norms (AFNOR, 2012)): one at the beginning of October (for pH measurements) when the canopy was in leaf, and the second in February ( $\mathrm{pH}$ and conductivity measurements) when the deciduous trees were bare. Throughfall was collected in pots anchored in the soil at 25 and $75 \mathrm{~cm}$ from the tree on the West side. Pots were protected by a mesh to prevent leaves or small animals falling in. Stemflow was collected in a $520 \mathrm{ml}$ cup attached to the West side of the trunk at $1 \mathrm{~m}$ in height. Cups were protected by an aluminum foil so that stemflow could fall in whereas direct rain could not.

\section{Statistical methods}

\section{Models}

We analyzed our data with Bayesian statistical models in order to estimate, analyze and compare the statistical models defined in the Supplementary Material, Table SM2. We chose Bayesian methods for two reasons. First, they allowed us to take into account the spatial autocorrelation among plots, thanks to spatially correlated plot random effects that have been found to give good results in a Bayesian framework (Saas and Gosselin, 2014). Indeed, even if this was not a case of complete pseudo-replication, the spatial distribution of the plots was not completely balanced since all the 
stands for a given composition tended to grow in the same area (Figure SM1). Second, they allowed us to take into account potential under- or over-dispersion of our species richness count data, thus ensuring better analyses than the Poisson law under frequentist models (Gosselin, 2011; Gosselin, 2015; Lynch et al., 2014).

We studied the effect of tree species identity and stand composition type (two main explanatory variables) on bryophyte species diversity, namely species richness, species abundance and species presence probability (Table SM1). Other environmental variables were considered either as single variables or as co-variables added to or in interaction with the two main variables (Table SM2).

Species richness being integer-value count data and being potentially under- or over-dispersed relative to the Poisson distribution, we modeled this variable following a new distribution law (Gosselin, 2011; Zilliox and Gosselin, 2014) which allows the dispersion parameter to be $<1$ or $>1$. We used the log function as the associated link function.

Ground species abundance data are numerical bounded between 0 and $N_{\max }$, where $\mathrm{N}_{\max }$ is the maximum value for one abundance record; we therefore modeled abundance with a beta-binomial or Polya distribution (Chen et al., 2008). We preferred a Polya distribution over a binomial one, since binomials tend to artificially "detect" effects where actually there are none, as when bounded data is over-dispersed (Gosselin, 2015). We used the logit function as the associated link function.

Trunk epiphyte abundance are cover class data, ranked in increasing order, characterized by values bounded between 0 and 100\%, asymmetric classes, and a high proportion of zeroes. They were modeled with a zero-inflated cumulative beta distribution, following the MTUnlimited method described in Herpigny and Gosselin, 2015 (2015). We used two logit functions to link the mean of the probability distributions to the linear combination of effects (one for the presence absence process, and one for the mean total cover process; cf. Herpigny and Gosselin, 2015).

Species presences are numerical data taking the values 0 and 1: species presence probabilities were modeled through logistic regressions with a binomial distribution. We used the logit function as the associated link function. We modeled presence probability at both tree and plot levels and only for sufficiently abundant species (more than 9 occurrences).

All the Bayesian models included a Gaussian spatially correlated plot random effect that was added to the linear combination used to calculate the mean of the model. The shape of the spatial dependence was exponential, with no nugget (function spatial.exp in Winbugs, with parameter k=1; i.e. the correlation $C_{i, j}$ between plots i and j separated by a distance of $d_{i, j}$ was $C_{i, j}=\exp \left(-\frac{d_{i, j}}{\varphi}\right)$ ). For mixed stand plot level data, the resulting "double data" (14 plots instead of 7) for the same plots had the same coordinates and therefore the same random effect. Doubling the data for mixed stands and simultaneously modeling plots' spatial autocorrelation as a spatially structured random effect was a way to use all the information provided by the six trees sampled in mixed stands, and yet to control the sampling effort per stand ( 3 trees and no more at stand level).

Since our models were hierarchical, with one random effect per observation, we compared their marginalized DIC (deviance information criterion) values (Millar, 2009) to identify the best model for each given response variable. The smaller the marginalized DIC, the better the model. 
The Bayesian models were fitted in R through the R2WinBUGS library calling WinBugs (Lunn et al., 2000) (including the extensions GeoBUGS for spatial autocorrelation modelling and the WBdev interface for some probability distributions). We used three trajectories of 100,000 iterations, a burning period of 10,000 iterations and a thinning parameter of 30 . The convergence of the model was checked with Gelman and Rubin's (1992) Rhat quantity, which was smaller than 1.1.

The prior distribution for the parameters of the spatially auto-correlated random effects were chosen as constrained, relatively non-informative values: the log of the inverse decay parameter $\varphi$ was chosen to be uniform between -11 and -3 , corresponding to a range of correlations from $2.10^{-9}$ to 0.99 and from 0 to 0.70 at the minimum $(401 \mathrm{~m})$ and maximum $(21,537 \mathrm{~m})$ distance between plots, respectively. The logarithm of the inverse of the variance had a uniform prior between -2 and 12 corresponding to a possible standard deviation from 0.0025 and 2.72. To compare marginalized DIC and select the best models, we had used a uniform distribution between -9 and -3 .

All the main fixed effects in the models - see Table SM2 - had a non-informative Gaussian prior with a mean of 0 and a variance of 10,000 .

The prior for the logarithm of the index of dispersion (ID) for count data models was chosen to be uniform between -1 to 5 - ranging from rather strong levels of under-dispersion (ID of 0.37) to high levels of over-dispersion (ID of 148) compared to the Poisson distribution. For the zero inflated cumulative beta distribution, the prior for parameter $\delta$ and the logarithm of $\Phi$, as described in Herpigny and Gosselin (2015), were rather non-informative and chosen as Gaussian with a mean of 0 and a variance of 10. For the beta-binomial Polya model, the over-dispersion parameter (with respect to the dispersion of the binomial distribution) followed a uniform distribution between 1 and 10,000. Analyses were performed with the R (version Rx64 2.15.1) and the WinBUGS14 (version 1.4) software.

Interpreting model results: analyzing the magnitude of the effect in addition to its statistical significance

For each response variable and for both main and - if different - best models, we not only analyzed the significance, but also the magnitude of the effect (Barbier et al., 2009b). We simulated a change in the explanatory variable (either an increase for numeric variables or a change of level for factors) and studied the magnitude of the consecutive change in the mean of the response variable. For numeric explanatory variables, the simulated increases were chosen with standardized values, namely the standard deviation of the variable and one fifth of its amplitude in the data set (Tables SM10, SM11, SM12). We checked that the resulting variations could be judged realistic in forest management.

We considered the magnitude of the effect negligible (even if statistically significant) if the variation $\Delta \mathrm{X}$ of the explanatory variable $\mathrm{X}$ led to a variation in the mean of the response variable that was less than $10 \%$ of the mean of the response variable's initial value. We analyzed two levels of magnitude: the effect was considered strong (respectively very strong) if the simulated increase in the explanatory variable led to a difference of more than $10 \%$ (respectively $20 \%$ ) in species number or in species abundance.

Based on Bayesian parameter estimation as in Camp et al. (2008), the aim of the magnitude analysis was to identify the following cases: 
(i) When the parameter had a high probability ( $\geq 95 \%)$ of being in the negligibility interval.

(ii) When the parameter had a high probability ( $\geq 95 \%)$ of being above the negligibility interval (positive, non-negligible effect).

(iii) When the parameter had a high probability ( $\geq 95 \%$ ) of being below the negligibility interval (negative, non-negligible effect).

The notations we adopted for the final interpretation of the model results are presented in Table SM3 and can be summarized as follows for the magnitude: + (respectively ++ ) : strong (respectively very strong) positive effect (difference of more than 10\%, respectively 20\%), - (respectively - - ): strong (respectively very strong) negative effect (difference of more than $10 \%$, respectively $20 \%$ ); nc : no possible conclusion about magnitude.

The same reasoning and notations apply to Polya abundance, cumulative beta or binomial presence probability data, taking into account the adapted logit link function. In each case, we report the mean value of the multiplier of the mean (equivalent to $\beta \Delta X$ in our example in Table SM3), its $95 \%$ confidence interval and the magnitude of the effect.

For statistical significance, the notations are: ${ }^{* *}=$ significant effect $(p<0.01),{ }^{*}=$ significant $(p<0.05), n s:$ non-significant effect.

\section{Results}

\section{Descriptive statistics}

We recorded a total of 29 species (among which eight were liverworts) on 84 trees and surrounding forest floor in the 21 plots - Table SM4. Four species occurred only on the ground, eight only on trunks while 17 species were found both on trunks and on the soil. Twenty-seven species occurred on oak and 13 on pine. Two species (Dicranum montanum Hedw. and Plagiothecium succulentum (Wilson) Lindb.) were found only on pine whereas 16 species were found only on oak (Table SM4).

At tree level, epiphyte species richness per tree ranged from two to seven species for oak, and from one to five species for pine. On the ground within one meter around the trunks, species richness ranged from one to twelve species for oak, and from one to seven species for pine (Table SM5). At plot level, global species richness ranged from eight to nineteen species in pure oak stands, three to eight species in pure pine stands and eight to fifteen species in mixed stands.

Observed $\mathrm{pH}$ values (Table SM6) were significantly higher on oak than on pine for bark, stemflow, throughfall (t-test, $p<0.01$ ) and for the organo-mineral horizon ( $t$-test, $p<0.05$ ). The difference was non-significant for soil surface horizon.

Bark pH values varied between 4.2 and 5.4 for oak, and between 4.0 and 4.9 for pine. Pine conductivity values were significantly higher than for oak for bark and February throughfall at $75 \mathrm{~cm}$ from the trunk ( $t$-test, $p<0.01$ ). The difference was non-significant for stemflow conductivity (Table SM6).

\section{Model results}

Effects of tree species identity on bryophyte diversity at tree-level - H1

Overall bryophyte diversity was higher on oak than on pine trees (See Table SM7 and Figure 1), thus confirming hypothesis $\mathrm{H} 1 \mathrm{a}$. Richness was significantly higher on/under oak than on/under pine, with 
a magnitude higher than $20 \%$ for both epiphytic and ground-species richness $(* * /++)$, and abundance as well, but only for epiphytic species.

Three species clearly had a higher probability of being present on or under pine (Table 1): Hypnum jutlandicum Holmen \& E.Warncke, Lophocolea heterophylla (Schrad.) Dumort. and Campylopus flexuosus (Hedw.) Brid., whereas seven species clearly occurred more frequently on or under oaks: Hypnum cupressiforme Hedw., Lophocolea bidentata (L.) Dumort., 1835, Frullania dilatata (L.) Dumort., Frullania tamarisci (L.) Dumort., Orthotrichum lyellii Hook. \& Taylor, Polytrichastrum formosum (Hedw.) G.L.Sm. and Thuidium tamariscinum (Hedw.) Schimp.

\section{Tree species identity and stand composition type effects interacted on bryophyte} diversity at tree-level - $\mathrm{H}_{2}$

Tree species identity and stand composition type had clearly interacting effects on bryophyte diversity (Table 2); taking this interaction into account enhanced the model in terms of marginalized DIC (Table SM8).

Bryophyte richness, whatever the species group considered (epiphyte, ground or global richness), was higher on and under pine trees in mixed stands compared to pure stands (Table 2). The estimated median of global richness was 4.42 species per tree in mixed stands and 3.08 species per tree in pure stands (more than 10\% higher). The difference was especially clear for epiphytic bryophyte richness, with 3.67 species per pine in mixed stands and 2.39 species per pine in pure stands (more than a $20 \%$ difference in species number). For oak, there was no significant difference between pure and mixed stands in global, epiphyte or ground species richness, and no conclusion on magnitude was possible.

The abundance of ground bryophytes under both pine and oak trees was higher in pure stands than in mixed stands (a difference of more than $20 \%$ in absolute cover under pines, $10 \%$ under oaks). Epiphyte abundance was not significantly different between mixed and pure stands, whatever the tree species.

In terms of bryophyte composition, mixture enhanced the probability of four species to be found on/under pine (Table 3): Campylopus flexuosus, Dicranum scoparium Hedw., Hypnum cupressiforme and Leucobryum glaucum (Hedw.) Ångstr. On the contrary, pure stands enhanced the probability to find Pseudoscleropodium purum (Hedw.) M.Fleisch under pine trees and Polytrichum formosum Hedw. under oak trees.

\section{Effect of stand composition type on bryophyte diversity at plot level - H3}

At the plot level, bryophyte communities in pure oak and mixed stands had similar richness for global, epiphytic and ground-species, and similar epiphyte species abundance, and all were higher $(* * /++)$ than in pure pine stands (Figure 2 and Table SM 9). Ground species abundance was higher in pure oak stands, with significant differences $(* /++)$ compared to mixed stands. Other comparisons between stands were not significant.

Bryophyte composition varied among stand types (Table 4). Three bryophyte species were more likely to occur in mixed stands compared to pure pine stands: Hypnum cupressiforme, Frullania dilatata (which occurred more frequently on oak trees; Table 1), and Campylopus flexuosus (which occurred more frequently on pine trees; Table 1). Seven species were more likely to occur in pure oak than in pure pine stands: Hypnum cupressiforme, Dicranum scoparium, Frullania dilatata, 
Frullania tamarisci, Polytrichum formosum, Thuidium tamariscinum - all of which are associated to oak trees; Table 1 - plus, surprisingly, Campylopus flexuosus, which is more frequently associated to pine trees but which did not occur in any of the pure pine stands in our study.

\section{Exploratory models for bryophyte richness and abundance - H4, H5 and H6} Effects of trunk and water supply characteristics on epiphytic bryophyte diversity (H4a)

When used as single explaining variables, bark and October stemflow $\mathrm{pH}$ had a strong positive effect on both epiphyte abundance and richness. Trunk diameter had a negative effect on epiphyte abundance. None of these effects remained significant once the tree species effect or the interaction with the stand composition effect had been taken into account.

Whether used as a single or additional variable, bark conductivity had a negligible effect on epiphyte richness and abundance. Neither stemflow conductivity nor trunk inclination had any significant effect.

Effects of trunk diameter, soil and throughfall chemical properties on ground bryophyte diversity $\underline{(H 4 b)}$

In addition to tree species effect, trunk diameter had a significant effect on ground bryophyte richness, but the magnitude analysis did not show any systematically clear strong positive effect $(* / n c)$. Adding trunk diameter to species*composition effect led to better DIC , but with no significant effect. Furthermore, trunk diameter had no significant effect on ground bryophyte abundance.

Whether used as a single or additional variable, $\mathrm{pH}$ and conductivity of February throughfall at $75 \mathrm{~cm}$ from the trunk had strong effects on both ground bryophyte abundance and richness (positive effect of $\mathrm{pH}^{* *} /++$, negative effect of conductivity $* * /--$, with a better DIC than the simple tree species effect model). These effects led to the best models explaining ground richness and abundance at $75 \mathrm{~cm}$ from the trunk (Tables SM10 and SM11). Data at $25 \mathrm{~cm}$ from the trunk revealed strong singlevariable effects of February throughfall $\mathrm{pH}(* /++)$ on ground bryophyte abundance, but no strong effect on ground bryophyte richness.

The $\mathrm{pH}$ and conductivity of October throughfall and of the substrates (organo-mineral horizon and soil surface $\mathrm{pH}$ ) had no effect on ground bryophyte richness or abundance, even though these variables appeared in some best models (Table SM10).

Effects of stand basal area and interfering understory plant cover on bryophyte diversity ( $\mathrm{H} 5-\mathrm{H} 6)$

Stand basal area generally had a strongly significant effect on bryophyte richness per tree, when considered in interaction with tree species identity and stand composition type. Taking basal area into account led to the best explicative models for epiphyte diversity, ground species abundance and global bryophyte richness per tree (see Tables SM10 and SM11). We found a very strong quadratic effect (**/successively $++/ 0 /--)$ of stand basal area on epiphyte richness, in addition to tree species identity and stand composition type (Table SM10).

At the plot level, basal area gave the best explanatory model for plot epiphytic richness, with a strong quadratic effect in addition to stand composition type (see Figure 3 and Tables SM12 and SM13 for 
the marginalized DIC values). Epiphytic and ground species abundance was also best explained by basal area taken as a single variable, with no possible conclusion about magnitude, however.

The cover of interfering plants had a strongly negative effect (*/-) on ground bryophyte abundance at $75 \mathrm{~cm}$ from the trunk, and gave the best explanatory model for under-tree ground bryophyte richness (See Table SM10) in addition to the species-composition interacting effect. However, the effect of interfering plant cover on total ground species abundance was negligible.

At the plot level, interfering plant cover used as a single variable had a significant effect on bryophyte richness (for both epiphytes and ground species). This effect did not remain significant when used in addition to stand composition effect, although it did enhance the DIC compared to the single "Stand composition type" model (and even led to the best model DIC for global richness - See Table SM12). Ground species richness at plot level remained best explained by stand composition alone.

Ground species abundance at the plot level was not influenced by interfering plant cover.

\section{Discussion}

\section{Effects of tree species identity and composition on bryophyte diversity at the tree and stand levels}

At both plot and tree levels, we found that pure oak and mixed stands tend to favour bryophyte diversity compared to pure pine stands.

Our hypothesis H1a was confirmed, with higher bryophyte diversity (richness and abundance) on oak than on pine trees. This confirms and extends previous findings (Kiraly and Odor, 2010) to other climatic and edaphic conditions, since the stands in our data set are growing on acidic soils in poor conditions. Bryophyte communities in our data set were relatively poor; even if we observed strong differences between phorophyte species or stand composition types, these differences actually represent a small number of species.

We found that, within similar climatic and edaphic conditions, some epiphytes or ground bryophytes were more likely to be associated with pine than with oak, and vice versa (Hypothesis $\mathrm{H} 1 \mathrm{~b})$. Our results confirm Kiraly and Odor's (2010) findings concerning the preference of Hypnum cupressiforme and Frullania dilatata for oak and the preference of Lophocolea heterophylla for pine. More species showed preferences for oak than for pine. This is similar to Cleavitt et al.'s (2009) and Wallrup et al.'s (2006) findings in their studies on small-scale tree-level floristic diversity; they found more species associated to the broadleaved trees than to conifers.

Mixed stands in our study enhanced bryophyte diversity on/under pine trees, confirming hypothesis $\mathrm{H} 2$. This result contributes interesting new knowledge, since no previous published study strictly compared pine (or oak) bryophyte diversity between pure and mixed stands. Cleavitt et al. (2009) also found a positive effect of mixed Acer rubrum-Picea rubens stands on epiphytic (lichen and bryophyte) richness on Acer rubrum trees, but did not study the effect on Picea rubens epiphytic diversity.

In addition, we found that preference of bryophyte species for a given phorophyte species was also influenced by stand composition (pure versus mixed), which confirms hypothesis H2: for example, Campylopus flexuosus was more likely to be found in mixed stands, under pine trees. This may be 
explained by less competition from interfering vascular plants, whose cover percentage was higher in pure pine than in mixed stands. Frullania dilatata was more likely to be found on oak trees in pure stands.

However, from a forest management point of view, results at the plot level (which is the management scale) are of higher importance than those at the tree level:

First, mixed stands hosted significantly richer bryophyte communities and more abundant epiphytic species than pure pine stands (confirming hypothesis $\mathrm{H} 3$ in this case), but not more than pure oak stands, which indeed had even more abundant ground bryophyte communities. This result may be due to the fact that we only took into account ground species within a radius of one meter around the trunks: ground species dwelling between trees were not taken into account. Such data are currently being collected on our Oak-Pine Tree Mixture (OPTMix) experimental design (Korboulewsky et al., 2015) and should clarify our results at the plot level. Our results are consistent with results obtained for soil fauna (Korboulewsky et al., 2016) and for floristic understory diversity (Barbier et al., 2008): diversity was generally influenced by the mixture of deciduous and coniferous tree species, but in almost all cases, maximum diversity was observed in one of the pure stands, not in the mixed stands, and in some cases no differences was observed between mixed and pure stands (Barsoum et al., 2014 for spider and carabid beetle richness).

Secondly, we did not find any bryophyte species exclusively associated with any one stand composition type, although we showed some trends - for example, Campylopus flexuosus was more likely to be found in mixed stands under pine trees, and Polytrichum formosum was more likely to be found under oak trees in pure than in mixed stands. As a consequence, bryophyte diversity at the landscape level should benefit from the simultaneous presence of the three stand composition types: pure oak, pure pine and mixed.

\section{Effects of the additional environmental variables on the bryophyte diversity}

Our exploratory models, based on an uncontrolled sampling design for the concerned variables, have good explanatory potential for the mechanisms behind the observed effects of tree species identity and stand composition type. Their results are valid within the conditions of our study (see Table SM6 for the domain of variation of our exploratory variables). They can be viewed as new hypotheses to future studies and are discussed below.

\section{Substrate or water supply chemistry effects}

Among all the variables related to substrate or water supply chemistry (hypothese $\mathrm{H} 4$ ), three appeared to have strong effects on bryophyte diversity in our study, namely (i) October stemflow $\mathrm{pH}$, with a strong positive effect on epiphytic richness and abundance; (ii) February throughfall pH, with a strong positive effect on ground species richness and abundance, whatever the distance from the stem; and (iii) February throughfall conductivity, with a strong negative effect on ground species richness and abundance at $75 \mathrm{~cm}$ from the stem.

We found that bryophyte communities associated with oak were richer and more abundant than the communities associated with pine. As far as epiphytic species richness is concerned, oak-pine 
bryophyte difference cannot be explained by competitive species cover according to Grime et al.'s (1990) theory, since richer bryophyte communities on oak were also more covering (mean epiphytic cover $=26.7 \%$ on oak, $1.95 \%$ on pine, $p<0.01$ for Student t-test). The oak-pine difference could be rather explained by differences in bark structure and chemistry between the two tree species, or by differences in water supply quantity and chemistry, as explained by previous authors, like Barkman (1958) and several authors cited in Kuusinen (1996).

Concerning bark, Barkman (1958) identified $\mathrm{pH}$ values from 3.7 to 5 for oak. In our study, the values were between 4.2 and 5.4 and differed significantly from pine bark pH values, which varied between 4 and 4.9. In comparison, Barkman (1958) and Kuusinen (1996) identified bark pH values well below 4 for pine. In our study, oak and pine bark also significantly differed in conductivity values, pine bark conductivity being higher, and in stemflow and throughfall $\mathrm{pH}$. Another frequently proposed explanation is that pine bark is dry and exfoliates considerably, thus providing an unsuitable, ephemeral habitat for bryophytes; whereas oak bark is rough, wrinkled and quite permanent and thus offers shady, moist long-lasting microhabitats more adapted to bryophytes (Barkman, 1958).

We did not assess the effect of water supply quantity in our study, but this variable also varies between tree species and may explain differences in bryophyte assemblages: in general, evergreen species like pine intercept a higher quantity of rainfall than do broadleaved species, leading to lower amounts of throughfall or stemflow in coniferous stands (Barbier et al., 2009a). According to Levia and Frost (2003), the greater amount of stemflow under broadleaved trees could increase soil water availability near the trunk and favor different flora than that found farther from the trunk.

We also chose to collect substrate and water supply data at $25 \mathrm{~cm}$ and at $75 \mathrm{~cm}$ from the trunk, because stemflow characteristics may influence soil pH and nutrient content in the immediate vicinity of the stem (Chang and Matzner, 2000a), but we did not find any significant effect of the distance on soil and throughfall $\mathrm{pH}$, contrary to the results of Beniamino et al. (1991) who observed soil acidification near Quercus robur L. trunks. The distance from the trunk influenced only February throughfall conductivity, which was significantly higher near the trunk (mean value $37 \mu \mathrm{S} \mathrm{cm}^{-1}$ ) than further away $\left(33 \mu \mathrm{S} \mathrm{cm}^{-1}\right)$. This could explain why this variable appeared in the best model explaining ground bryophyte richness in addition to the tree species effect.

Our results lead us to believe that the phorophyte species effect on bryophyte richness and abundance cannot be reduced to a simple linear effect of substrate or water supply characteristics; first, because these variables were not strongly correlated with tree species (except for stemflow pH values, strongly correlated to pine); secondly, because these variables, when individually taken as simple explanation variables, gave models whose DIC were worse than the simple species model. It is more likely that tree species effect reflected a combination of diverse substrate or water supply characteristics. As far as epiphytic species are concerned, this is quite different with Cleavitt et al.'s (2011) results, that showed that epiphytic diversity was determined first by stemflow pH and only secondly by the tree species. However, Cleavitt et al.'s (2011) results were for epiphytic composition, whereas we tested substrate or water supply variables only for epiphytic richness and abundance. Our results show phorophyte species as the main explanatory factor for bryophyte diversity at tree level under homogeneous climatic conditions; this is consistent with Kiraly et al. (2013) and Odor et al. (2013). 
Hypotheses $\mathrm{H} 5$ and $\mathrm{H} 6$ were not supported, as the effect of basal area on epiphytic richness was strongly quadratic, rather than linear decreasing. Furthermore, the effect was positive rather than negative for global richness. Finally, basal area effect was positive on bryophyte abundance. The quadratic effect of basal area on epiphytic richness may be due to a positive "substrate availability" effect in the first part of the gradient of basal area values (18 to $\left.40 \mathrm{~m}^{2} \mathrm{ha}^{-1}\right)$, and to a negative "competition for light" effect in the second part of the gradient. The switch between the positive and negative part of the basal area effect occurs between 25 and $30 \mathrm{~m}^{2}$ ha ${ }^{-1}$. Kiraly et al. (2013) found a negative effect of stand density, expressed as number of trees per hectare. Their study dealt with mixed broadleaved-coniferous stands in Hungary where basal area was between 24 and $34 \mathrm{~m}^{2} \mathrm{ha}^{-1}$, a gradient that is situated within the second part of our gradient.

Our exploratory results involving interfering vascular plant cover suggested a weakly significant negative effect on the abundance of ground bryophyte species at tree level and on global richness at the plot level. This trend is not consistent with Kiraly et al. (2013) and Marialigeti et al. (2009) who showed a positive effect of the shrub and understory herb. Two different mechanisms may be at work: competition for light between interfering plants and the bryophyte layer may explain the negative effects observed in our study, whereas suitable shady conditions provided by the shrub layer could explain the positive effects observed in Kiraly et al. (2013). These apparently inconsistent results may also be explained by the fact that the shrub layer in Kiraly et al. (2013) and the herbaceous layer in Marialigeti et al. (2009) belonged to other strata (either ligneous higher than 50 $\mathrm{cm}$ or herbaceous under $50 \mathrm{~cm}$ ) than the interfering plants (mostly herbaceous or semi-ligneous over $50 \mathrm{~cm}$ ) in our study.

\section{Conclusion}

Within the context of our study (mature stands, floodplain oak and pine temperate forests in acidic conditions with variable humidity), mixed stands clearly enhanced the bryophyte diversity on pine at tree level and hosted bryophyte communities of similar richness as pure oak stands at the stand level. The bryophyte diversity in pure pine stands was clearly poorer than in oak or mixed stands. However, since some species were found preferably on pines, either in pure stands (e.g. Lophocolea heterophylla) or in mixed stands (e.g. Campylopus flexuosus), we conclude that bryophyte diversity at the landscape level should benefit from the simultaneous presence of the three stand composition types: pure oak, pure pine and mixed. Within the basal area gradient of the studied stands, an increase in basal area appears to generally increase overall bryophyte diversity, but may diminish epiphytic richness in the higher part of the gradient. Current forest management guidelines encourage decreasing stand density in order to adapt the forest to climate change by reducing stand water consumption, and this may be detrimental for bryophyte diversity. Exploratory models suggest a strong effect of water supply chemistry which could partially, but not entirely, explain the phorophyte species effect on bryophyte richness and abundance.

\section{Acknowledgements}

This research was supported by the French Ministry of the Environment (ISCAR and DivClim Projects) and carried out on a part of the OPTMix (Oak Pine Tree Mixture) experimental site 
(http://optmix.irstea.fr/), managed by Irstea and supported by the Centre-Val de Loire region and the French National Forest Office. This site belongs to the SOERE F-ORE-T which is supported annually by Ecofor, Allenvi and the french national research infrastructure ANAEE-F (http://www.anaee-france.fr/fr/).

We especially thank Catherine Menuet, Franck Stocchero and Sébastien Macé for their help with field and laboratory work; Victoria Moore for her help in improving the English style; Peter Odor and an anonymous reviewer for their useful comments on the manuscript.

\section{References}

AFNOR, 1996. Qualité du sol - Détermination du pH - Norme ISO 10390. AFNOR (Association Française de Normalisation), Paris.

AFNOR, 2012. Qualité de l'eau - Détermination du pH - Norme ISO 10523. AFNOR (Association Française de Normalisation), Paris.

Aude, E., Poulsen, R. S., 2000. Influence of management on the species composition of epiphytic cryptogams in Danish Fagus forests. Applied Vegetation Science, 3 (1), 81-88.

Barbier, S., Balandier, P., Gosselin, F., 2009a. Influence of several tree traits on rainfall partitioning in temperate and boreal forests: a review. Annals of Forest Science, 66 (602).

Barbier, S., Chevalier, R., Loussot, P., Bergès, L., Gosselin, F., 2009b. Improving biodiversity indicators of sustainable forest management: tree genus abundance rather than tree genus richness and dominance for understory vegetation in French lowland oak hornbeam forests. Forest Ecology and Management, 258 (Supplement), S176-S186.

Barbier, S., Gosselin, F., Balandier, P., 2008. Influence of tree species on understory vegetation diversity and mechanisms involved - a critical review for temperate and boreal forests. Forest Ecology and Management, 254 (1), 1-15.

Barkman, J.J., 1958. Phytosociology and ecology of cryptogamic epiphytes, including a taxonomic survey and description of their vegetation units in Europe. Van Gorcum \& Comp. N.V., Assen, 628p.

Barsoum, N., Fuller, L., Ashwood, F., Reed,K., Bonnet-Lebrun, A.-S. et al., 2014. Grounddwelling spider (Araneae) and carabid beetle (Coleoptera: Carabidae) community assemblages in mixed and monoculture stands of oak (Quercus robur L./Quercus petraea (Matt.) Liebl.) and Scots pine (Pinus sylvestris L.). Forest Ecology and Management, 321, 2941.

Bates, J.W., 1992. Influence of chemical and physical factors on Quercus and Fraxinus epiphytes at Loch Sunart, Western Scotland - A multivariate analysis. Journal of Ecology, 80 (1), 163-179.

Bates, J.W., Brown, D.H., 1981. Epiphyte differentiation between Quercus petraea and Fraxinus excelsior trees in a maritime area of South West England. Vegetatio, 48, 61-70. 
Beniamino, F., Ponge, J.F., Arpin, P., 1991. Soil acidification under the crown of oak trees: I. Spatial distribution. Forest Ecology and Management, 40 (3-4), 221-232.

Brandtberg, P., Lundkvist, H., 2004. Does an admixture of Betula species in Picea abies stands increase organic matter quality and nitrogen release? Scandinavian Journal of Forest Research, 19 (2), 127-141.

Brandtberg, P.O., Lundkvist, H., Bengtsson, J., 2000. Changes in forest-floor chemistry caused by a birch admixture in Norway spruce stands. Forest Ecology and Management, 130 (1-3), 253-264.

Camp, R.J., Seavy, N.E., Gorresen, P.M., Reynolds, M.H., 2008. A statistical test to show negligible trend: Comment. Ecology, 89 (5), 1469-1472.

Cannell, M., Malcolm, D., Robertson, P. (Eds.), 1992. The ecology of mixed-species stands of trees. Oxford Blackwell Scientific Pub., London, 312 p.

Cavard, X., Bergeron, Y., Chen, H.Y., Paré, D., 2011a. Effect of forest canopy composition on soil nutrients and dynamics of the understorey: Mixed canopies serve neither vascular nor bryophyte strata. Journal of Vegetation Science, 22 (6), 1105-1119.

Cavard, X., Macdonald, S.E., Bergeron, Y., Chen, H., 2011b. Importance of mixedwoods for biodiversity conservation: Evidence for understory plants, songbirds, soil fauna, and ectomycorrhizae in northern forests. Environmental Reviews, 19, 141-161.

Chang, S.C., Matzner, E., 2000a. Soil nitrogen turnover in proximal and distal stem areas of European beech trees. Plant and Soil, 218 (1-2), 117-125.

Chang, S.C., Matzner, E., 2000b. The effect of beech stemflow on spatial patterns of soil solution chemistry and seepage fluxes in a mixed beech/oak stand. Hydrological Processes, 14 (1), 135-144.

Chen, J., Shiyomi, M., Hori, Y., Yamamura, Y., 2008. Frequency distribution models for spatial patterns of vegetation abundance. Ecological Modelling, 211 (3-4), 403-410.

Cleavitt, N., Ewing, H., Weathers, K., Lindsey, A., 2011. Acidic atmospheric deposition interacts with tree type and impacts the cryptogamic epiphytes in Acadia National Park, Maine, USA. Bryologist, 114 (3), 570-582.

Cleavitt, N.L., Dibble, A.C., Werier, D.A., 2009. Influence of tree composition upon epiphytic macrolichens and bryophytes in old forests of Acadia National Park, Maine. Bryologist, 112 (3), 467-487.

del Rio, M., Sterba, H., 2009. Comparing volume growth in pure and mixed stands of Pinus sylvestris and Quercus pyrenaica. Annals of Forest Science, 66 (5), 502 (p1)-502 (p11).

Dumas, Y., 2006. Espèces interférentes. In: Gama, A. (Ed.), Guide Pratique - Utilisation des herbicides en forêt et gestion durable. Ministère de l'Agriculture et de la Pêche - Office National des Forêts, pp. 181-221. 
Farmer, A., Bates, J., Bell, J., 1991. Seasonal variations in acidic pollutant inputs and their effects on the chemistry of stemflow, bark and epiphyte tissues in three oak woodlands in N.W. Britain. New Phytologist, 118 (441), 451.

Felton, A., Lindbladh, M., Brunet, J., Fritz, Ö., 2010. Replacing coniferous monocultures with mixed-species production stands: An assessment of the potential benefits for forest biodiversity in northern Europe. Forest Ecology and Management, 260 (6), 939-947.

Fritz, Ö., Heilmann-Clausen, J., 2010. Rot holes create key microhabitats for epiphytic lichens and bryophytes on beech (Fagus sylvatica). Biological Conservation, 143 (4), 1008-1016.

Gargominy, O., Tercerie, S., Régnier, C., Ramage, T., Schoelinck, C. et al., 2015. TAXREF v9.0, référentiel taxonomique pour la France : méthodologie, mise en œuvre et diffusion. SPN-2015-64, Museum National d'Histoire Naturelle, Service du Patrimoine Naturel, Paris.

Gelman, A., Rubin, D.B., 1992. Inference from iterative simulation using multiple sequences. Statistical Science, 7, 457-511.

Gonzalez-Mancebo, J., Losada-Lima, A., McAlister, S., 2003. Host specificity of epiphytic bryophyte communities of a laurel forest on Tenerife (Canary Islands, Spain). The Bryologist, 106 (3), 383-394.

Gosselin, F., 2011. Propositions pour améliorer l'équipement biométrique du détective écologique. Application à la modélisation de la relation entre gestion forestière et biodiversité. HDR Thesis, Université Pierre et Marie Curie, Paris.

Gosselin, F., 2015. Reevaluating Europe's other debt with improved statistical tools. Biodiversity and Conservation, 24(1), 205-211.

Grime, J.P., Rincon, E., Wickerson, B., 1990. Bryophytes and plant strategy theory. Botanical journal of Linnean Society, 104, 175-186.

Gustafsson, L., Eriksson, I., 1995. Factors of importance for the epiphytic vegetation of aspen Populus tremula with special emphasis on bark chemistry and soil chemistry. Journal of Applied Ecology, 32 (2), 412-424.

Herpigny, B., Gosselin, F., 2015. Analyzing plant cover class data quantitatively: customized cumulative zero-inflated beta distributions show promising results. Ecological Informatics, 26 (3), 18-26.

Jactel, H., Brockerhoff, E., Duelli, P., 2005. A test of the biodiversity-stability theory: Metaanalysis of tree species diversity effects on insect pest infestations, and re-examination of responsible factors. In: Scherer-Lorenzen, M., Körner, C. and Schulze, E. (Eds.), Forest Diversity and Function. Ecological Studies Series.. Springer-Verlag, pp. 235-254.

Jactel, H., Brockerhoff, E.G., 2007. Tree diversity reduces herbivory by forest insects. Ecology Letters, 10 (9), 835-848. 
Kiraly, I., Nascimbene, J., Tinya, F., Odor, P., 2013. Factors influencing epiphytic bryophyte and lichen species richness at different spatial scales in managed temperate forests. Biodiversity and Conservation, 22 (1), 209-223.

Kiraly, I., Odor, P., 2010. The effect of stand structure and tree species composition on epiphytic bryophytes in mixed deciduous-coniferous forests of Western Hungary. Biological Conservation, 143 (9), 2063-2069.

Korboulewsky, N., Perez, G., Chauvat, M., 2016. How tree diversity affects soil fauna diversity: A review. Soil Biology and Biochemistry, 94, 94-106.

Korboulewsky, N., Perot, T., Balandier, P., Ballon, P., Barrier, R. et al., 2015. OPTMix Dispositif expérimental de suivi à long terme du fonctionnement de la forêt mélangée. Rendez-Vous Techniques de l’ONF, 47, 60-70.

Koricheva, J., Vehvilainen, H., Riihimaki, J., Ruohomaki, K., Kaitaniemi, P. et al., 2006. Diversification of tree stands as a mean to manage pests and diseases in boreal forests: myth or reality? Canadian Journal of Forest Research, 36 (2), 324-336.

Kriebitzsch, W.U., Bültmann, H., von Oheimb, G., Schmidt, M., Thiel, H. et al., 2013. Forestspecific diversity of vascular plants, bryophytes and lichens. In: Kraus, D. and Krumm, F. (Eds.), Integrative approaches as an opportunity for the conservation of forest biodiversity. In Focus - Managing Forest in Europe.. European Forest Institute, pp. 158-169.

Kuusinen, M., 1996. Epiphyte flora and diversity on basal trunks of six old-growth forest tree species in southern and middle boreal Finland. Lichenologist, 28, 443-463.

Leith, I., Mitchell,R.J., Truscott,A.M., Cape,J.N., van Dijk, .. et al., 2008. The influence of nitrogen in stemflow and precipitation on epiphytic bryophytes, Isothecium myosuroides Brid., Dicranum scoparium Hewd. and Thuidium tamariscinum (Hewd.) Schimp of Atlantic oakwoods. Environmental Pollution, 155 (2), 237-246.

Levia, D.F., Frost, E.E., 2003. A review and evaluation of stemflow literature in the hydrologic and biogeochemical cycles of forested and agricultural ecosystems. Journal of Hydrology, 274 (1-4), 1-29.

Lubbe, T., Schuldt, B., Coners, H., Leuschner, C., 2016. Species diversity and identity effects on the water consumption of tree sapling assemblages under ample and limited water supply. Oikos, 125 (1), 86-97.

Lunn, D.J., Thomas, A., Best, N., Spiegelhalter, D., 2000. WinBUGS - A Bayesian modelling framework: Concepts, structure, and extensibility. Statistics and Computing, 10 (4), 325-337.

Lygis, V., Vasiliauskas, R., Stenlid, J., Vasiliauskas, A., 2004. Silvicultural and pathological evaluation of Scots pine afforestations mixed with deciduous trees to reduce the infections by Heterobasidion annosum s.s. Forest Ecology and Management, 201 (2-3), 275-285.

Lynch, H.J., Thorson, J.T., Shelton, A.O., 2014. Dealing with under- and over-dispersed count data in life history, spatial, and community ecology. Ecology, 95 (11), 3173-3180. 
Marialigeti, S., Nemeth, B., Tinya, F., Odor, P., 2009. The effects of stand structure on ground-floor bryophyte assemblages in temperate mixed forests. Biodiversity and Conservation, 18 (8), 2223-2241.

McGee, G., Kimmerer, R., 2002. Forest age and management effects on epiphytic bryophyte communities in Adirondack northern hardwood forests, New York, U.S.A. Canadian Journal of Forest Research, 32 (9), 1562-1576.

Migge, S., Maraun, M., Scheu, S., Schaefer, M., 1998. The oribatid mite community (Acarina) of pure and mixed stands of beech (Fagus sylvatica) and spruce (Picea abies) of different age. Applied Soil Ecology, 9 (1-3), 115-121.

Millar, R.B., 2009. Comparison of hierarchical bayesian models for overdispersed count data using DIC and Bayes' factors. Biometrics, 65 (3), 962-969.

Nagano, I., 1972. On the relations of the chemical composition of some mosses to their substrate rocks. Journal of the Hattori Botanical Laboratory, 35, 391-398.

Neite, H., Wittig, R., 1985. Correlation of chemical soil pattern with the floristic pattern in the trunk base area of the beech. Acta Oecologica, 6 (4), 375-385.

Odor, P., Kiraly, I., Tinya, F., Bortignon, F., Nascimbene, J., 2013. Patterns and drivers of species composition of epiphytic bryophytes and lichens in managed temperate forests. Forest Ecology and Management, 306, 256-265.

Oxbrough, A., French, V., Irwin, S., Kelly, T.C., Smiddy, P. et al., 2012. Can mixed species stands enhance arthropod diversity in plantation forests? Forest Ecology and Management, 270, 11-18.

Parrotta, J.A., 1999. Productivity, nutrient cycling, and succession in single- and mixedspecies plantations of Casuarina equisetifolia, Eucalyptus robusta, and Leucaena leucocephala in Puerto Rico. Forest Ecology and Management, 124 (1), 45-77.

Pérot, T., Picard, N., 2012. Mixture enhances productivity in a two-species forest: evidence from a modeling approach. Ecological Research, 27 (1), 83-94.

Perot, T., Vallet, P., Archaux, F., 2013. Growth compensation in an oak-pine mixed forest following an outbreak of pine sawfly (Diprion pini). Forest Ecology and Management, 295 (0), 155-161.

Pretzsch, H., 2003. Diversity and productivity of forests. Allgemeine Forst Und Jagdzeitung, 174 (5-6), 88-98.

Raabe, S., Müller, J., Manthey, M., Dürhammer, O., Teuber, U. et al., 2010. Drivers of bryophyte diversity allow implications for forest management with a focus on climate change. Forest Ecology and Management, 260 (11), 1956-1964.

Saas, Y., Gosselin, F., 2014. Simulation-based comparative analysis of spatial count regression methods on regularly and irregularly-spaced locations. Ecography, 37 (5), 476-489. 
Scheu, S., Albers, D., Alphei, J., Buryn, R. , Klages, U., Migge, S. et al., 2003. The soil fauna community in pure and mixed stands of beech and spruce of different age: trophic structure and structuring forces. Oikos, 101 (2), 225-238.

Simmons, E.A., Buckley, G.P., 1992. Ground vegetation under planted mixtures of trees. In: Cannell, M.G.R., Malcolm, D.C. and Robertson, P.A. (Eds.), The ecology of mixed-species stands of trees. Blackwell Scientific Publications, Oxford, pp. 211-231.

Smith, K.W., 1992. Birds populations: effects of tree species mixtures. In: Cannell, M.G.R., Malcolm, D.C. and Robertson, P.A. (Eds.), The ecology of mixed-species stands of trees. Blackwell Scientific Pub., Oxford, pp. 233-242.

Sobek, S., Gossner, M., Scherber, C., Steffan-Dewenter, I., Tscharntke, T., 2010. Tree diversity drives abundance and spatiotemporal beta-diversity of true bugs (Heteroptera). Ecological Entomology, 34 (6), 772-782.

Sutinen, R., Teirila, A., Panttaja, M., Sutinen, M.L., 2002. Distribution and diversity of tree species with respect to soil electrical characteristics in Finnish Lapland. Canadian Journal of Forest Research, 32 (7), 1158-1170.

Tinya, F., Márialigeti, S., Király, I., Németh, B., Ódor, P., 2009. The effect of light conditions on herbs, bryophytes and seedlings of temperate mixed forests in Orség, Western Hungary. Plant Ecology, 204 (1), 69-81.

Toïgo, M., Vallet, P., Perot, T., Bontemps, J., Piedallu, C. et al., 2015. Overyielding in mixed forests decreases with site productivity. Journal of Ecology, 103 (2), 505-512.

Vallet, P., Pérot, T., 2011. Silver fir stand productivity is enhanced when mixed with Norway spruce: evidence based on large-scale inventory data and a generic modelling approach. Journal of Vegetation Science, 22, 932-942.

Vaychis, M., Danusyavichus, Y.u., 1978. Effect of birch on soil properties in a pine plantation. Pochvovedenie (1), 113-123.

Vellak, K., Paal, J., Liira, J., 2003. Diversity and distribution pattern of bryophytes and vascular plants in a boreal spruce forest. Silva Fennica, 37 (1), 3-13.

Virtanen, R., Johnston, A.E., Crawley, M.J., Edwards, G.R., 2000. Bryophyte biomass and species richness on the Park Grass Experiment, Rothamsted, UK. Plant Ecology, 151 (2), 129141.

Wallrup, E., Saetre, P., Rydin, H., 2006. Deciduous trees affect small-scale floristic diversity and tree regeneration in conifer forests. Scandinavian Journal of Forest Research, 21 (5), 399404.

Watt, A.D., 1992. Insect pest population dynamics: effects of tree species diversity. In: Cannell, M.G.R., Malcolm, D.C. and Robertson, P.A. (Eds.), The ecology of mixed-species stands of trees. Blackwell Scientific Pub., Oxford, pp. 267-275. 
809 Wittig, R., Neite, H., 1985. Acid indicators around the trunk base of Fagus sylvatica in

810 limestone and loess beechwoods: distribution pattern and phytosociological problems.

811 Vegetatio, 64 (2-3), 113-119.

812 Zilliox, C., Gosselin, F., 2014. Tree species diversity and abundance as indicators of

813 understory diversity in French mountain forests: Variations of the relationship in geographical

814 and ecological space. Forest Ecology and Management, 321, 105-116.

$815 \quad$ Figures

816 

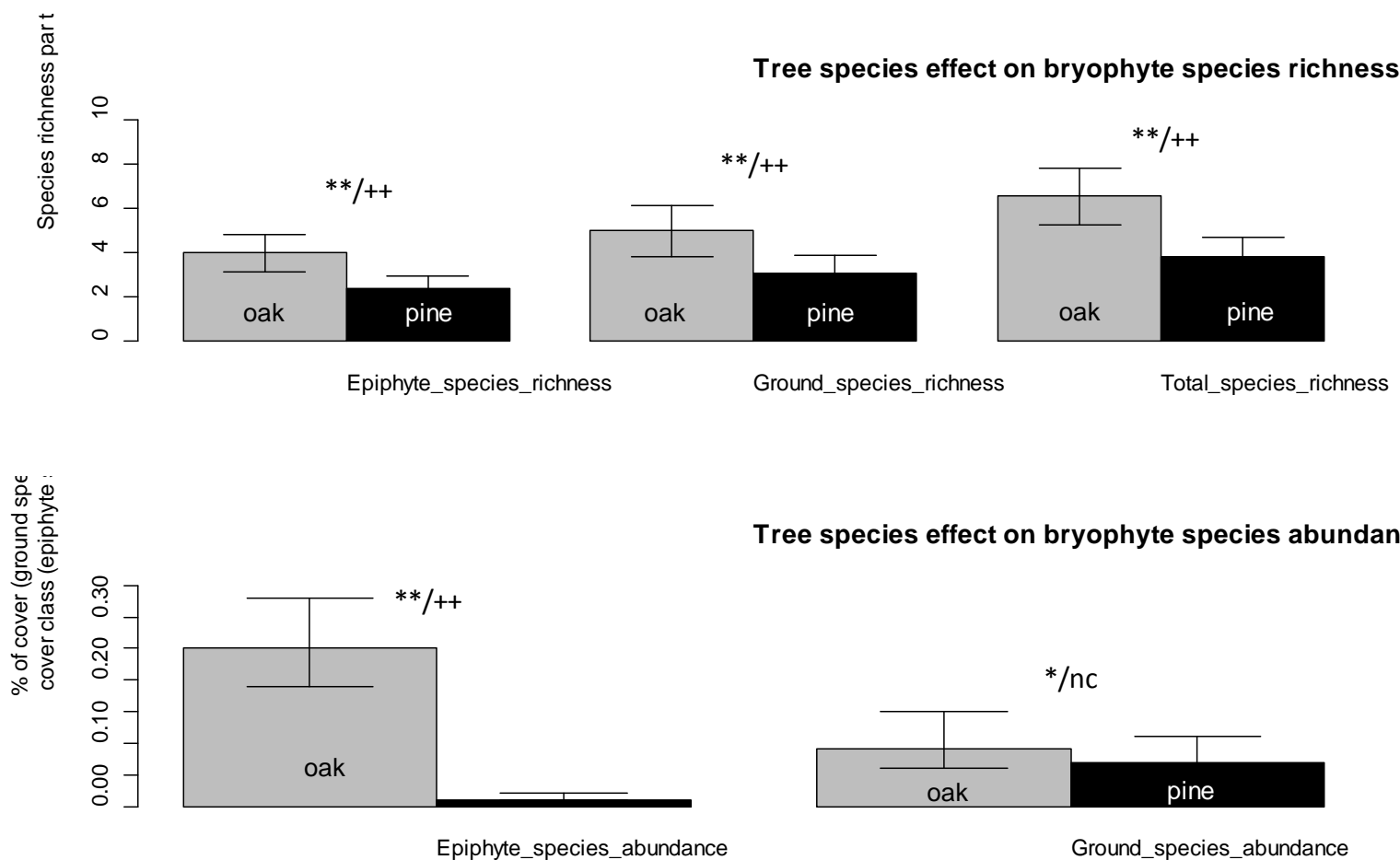

Tree species effect on bryophyte species abundance

818

819

820

821

822

823
Figure 1. Tree species effect on bryophyte diversity at tree level: oak-pine difference for epiphyte, ground and total bryophyte species richness, for epiphyte species abundance and for ground-species abundance. ${ }^{* *}=\operatorname{significant~}(p<0.01)$, $*=$ significant $(\mathrm{p}<0.05),++$ : very strong effect (more than $20 \%$ species (or cover) more on oak), nc: non conclusive magnitude of the effect. 


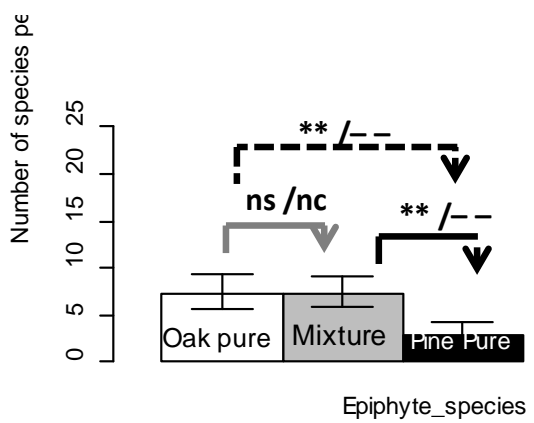

Epiphyte_species

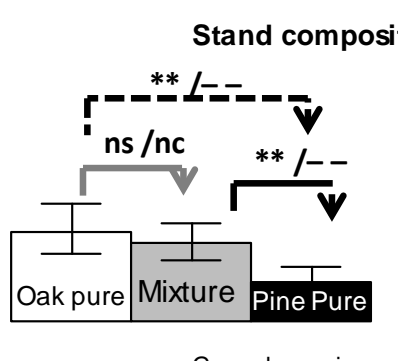

Ground_species

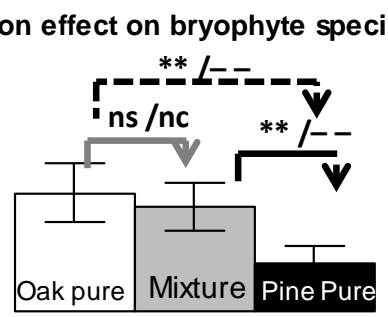

Global

흠

离

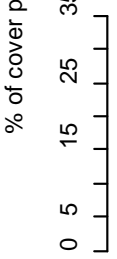

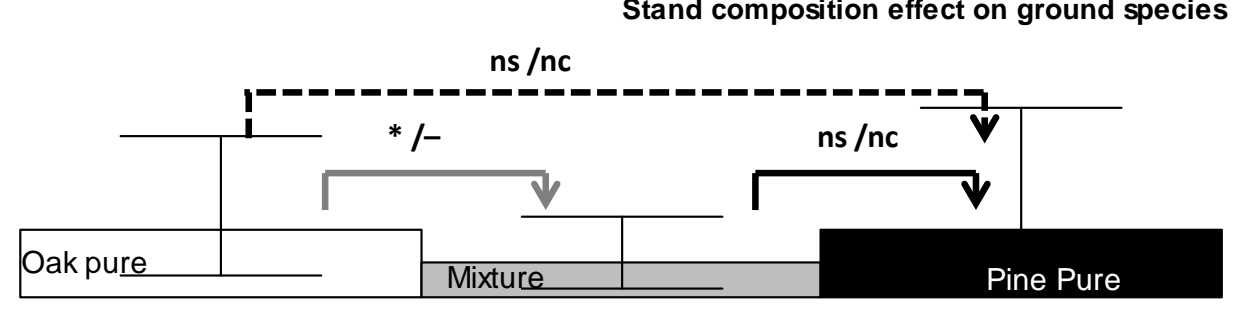

Ground_species_abundance

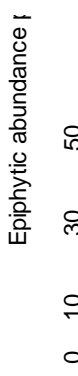

Stand composition effect on epiphyte species abun $\left.\begin{array}{l}\text { ㅇ } \\ 0 \\ 0 \\ 0 \\ 0 \\ 0\end{array}\right]$

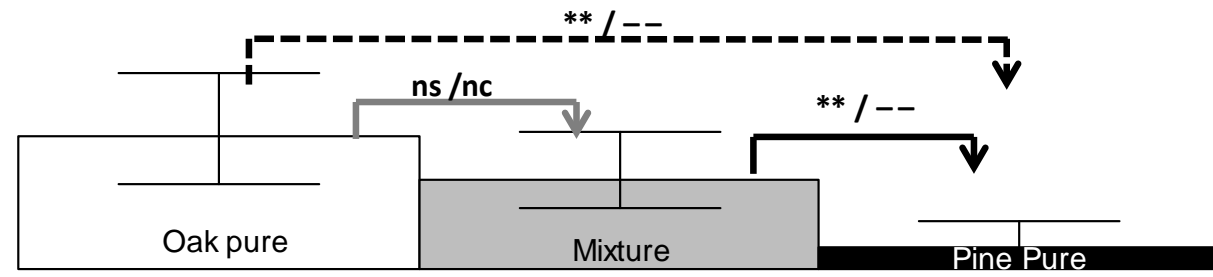

Epiphyte_species_abundance

Figure 2. Stand composition effect on bryophyte diversity at "plot" level (group of three trees): differences between pure oak, pure pine and mixed stands are given for epiphytes, ground species and global species richness (top graph), for ground species abundance within $1 \mathrm{~m}$ around the trunks, assessed as a percentage of cover (middle) and for epiphyte species abundance, assessed in mean percentage of cover. Grey line: differences between pure oak and mixed stands. Black line: differences between pure pine and mixed stands. Dotted line: differences between pure oak and pure pine stands. ${ }^{* *}=$ significant $(p<0.01),{ }^{*}=$ significant $(p<0.05), n s=$ non-significant, -- : very strong difference (magnitude more 


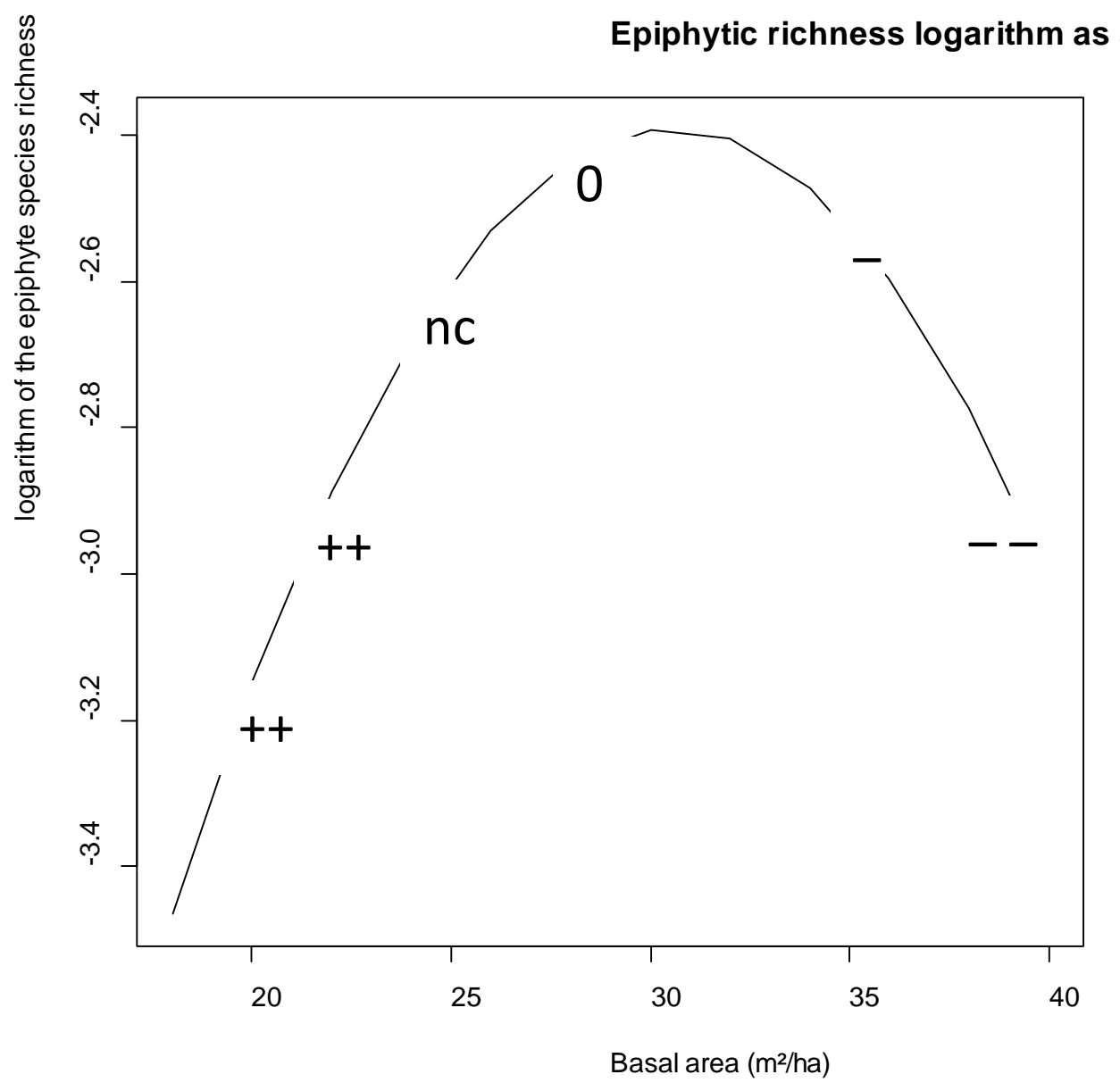

833

834 Figure 3. Quadratic effect of basal area on epiphyte richness at plot level. The values here illustrate the case of pure oak stands and do not include the inter-plot variability (random effects). ${ }^{* *}=$ significant $(p<0.01),{ }^{*}=$ significant $(p<0.05)$, ns=non-significant, - -: very strong difference (magnitude more than $20 \%$ ), -: strong difference (magnitude more than $10 \%)$, nc: non conclusive magnitude of the effect. 


\section{Tables}

Table 1. Tree level presence probabilities of bryophyte species on (or under) oak and pine, regardless of stand composition type, and magnitude analysis of the oak-pine difference (Hypothesis H1). Presence probabilities were estimated through logistic regression for the most frequent species (at least nine occurrences). The values here do not include the inter-plot variability (random effects)

\begin{tabular}{|c|c|c|c|c|c|}
\hline \multirow[b]{2}{*}{ SPECIES } & \multirow[b]{2}{*}{$\begin{array}{l}\text { Number of } \\
\text { occurrences }\end{array}$} & \multirow[b]{2}{*}{$\begin{array}{c}\text { Presence } \\
\text { probability on oak } \\
\text { (0) }\end{array}$} & \multirow[b]{2}{*}{$\begin{array}{c}\text { Presence } \\
\text { probability on } \\
\text { pine }(P) \\
\end{array}$} & \multicolumn{2}{|c|}{$\begin{array}{c}\text { Difference } \\
\text { (analyzed ratio: } \mathrm{O} / \mathrm{P} \text { ) }\end{array}$} \\
\hline & & & & significance & Magnitude \\
\hline Hypnum jutlandicum Holmen \& E.Warncke & 54 & $0.36[0.18 ; 0.55]$ & $0.92[0.8 ; 0.99]$ & * & -- \\
\hline Hypnum cupressiforme Hedw. & 63 & $1.00[1.00 ; 1.00]$ & $0.49[0.13 ; 0.86]$ & $*$ & ++ \\
\hline Lophocolea heterophylla (Schrad.) Dumort. & 24 & $0.12[0.04 ; 0.26]$ & $0.43[0.26 ; 0.61]$ & $*$ & -- \\
\hline Campylopus flexuosus (Hedw.) Brid. & 10 & $0.02[0.001 ; 0.11]$ & $0.09[0.01 ; 0.31]$ & $*$ & -- \\
\hline Lophocolea bidentata (L.) Dumort., 1835 & 9 & $0.12[0.02 ; 0.37]$ & $0.00[0.00 ; 0.00]$ & $*$ & ++ \\
\hline Dicranum scoparium Hedw. & 62 & $0.89[0.59 ; 0.98]$ & $0.68[0.36 ; 0.92]$ & ns & $\mathrm{nc}$ \\
\hline Frullania dilatata (L.) Dumort. & 24 & $0.59[0.38 ; 0.79]$ & $0.00[0.00 ; 0.00]$ & $*$ & ++ \\
\hline Frullania tamarisci (L.) Dumort. & 12 & $0.2[0.05 ; 0.48]$ & $0.00[0.00 ; 0.00]$ & $*$ & ++ \\
\hline Leucobryum glaucum (Hedw.) Angstr. & 16 & $0.20[0.05 ; 0.39]$ & $0.1[0.03 ; 0.25]$ & ns & nc \\
\hline Orthotrichum lyellii Hook. \& Taylor & 9 & $0.13[0.03 ; 0.37]$ & $0.00[0.00 ; 0.00]$ & * & ++ \\
\hline Pleurozium schreberi (Willd. ex Brid.) Mitt. & 15 & $0.13[0.03 ; 0.34]$ & $0.1[0.02 ; 0.28]$ & ns & nc \\
\hline Polytrichum formosum Hedw. & 37 & $0.85[0.6 ; 0.97]$ & $0.05[0.006 ; 0.2]$ & * & ++ \\
\hline \multicolumn{6}{|l|}{ Pseudoscleropodium purum (Hedw.) } \\
\hline M.Fleisch. & 57 & $0.83[0.52 ; 0.97]$ & $0.8[0.45 ; 0.96]$ & ns & $\mathrm{nc}$ \\
\hline Thuidium tamariscinum (Hedw.) Schimp. & 26 & $0.49[0.29 ; 0.68]$ & $0.09[0.03 ; 0.22]$ & * & ++ \\
\hline
\end{tabular}

$\mathrm{ns}=$ non-significant, $\mathrm{nc}=$ no possible conclusion about the effect magnitude, $*=$ significant $(\mathrm{p}<0.05),{ }^{* *}=$ significant $(\mathrm{p}<0.01),--=\mathrm{very}$ strong negative effect (probability higher by more than $20 \%$ on pine), $++=$ very strong positive effect (probability higher by more than $20 \%$ on oak). The values (means and $95 \%$ confidence intervals) are rounded to two decimal places. 
Table 2. Mean estimated bryophyte species richness and abundance values on oak and on pine, in pure compared to mixed stands (Hypothesis $\mathbf{H 2}$ ), with their $95 \%$ confidence intervals, and analysis of the pure-mixed difference: the stand composition effect depends on tree species identity. The values here do not include the inter-plot variability (random effects).

\begin{tabular}{|c|c|c|c|c|c|c|c|}
\hline Tree level & & & $\begin{array}{l}\text { SRglob } \\
(n=84)\end{array}$ & $\begin{array}{c}\text { SRepiph } \\
(n=84)\end{array}$ & $\begin{array}{c}\text { SRground } \\
(\mathrm{n}=84)\end{array}$ & $\begin{array}{c}\text { ABground/N } \\
(n=84)\end{array}$ & $\begin{array}{c}\text { ABepiph } \\
(\mathbf{n}=\mathbf{8 4})\end{array}$ \\
\hline \multirow{4}{*}{ On oak } & \multirow{2}{*}{ Composition } & Pure & $7.23[5.44 ; 9.41]$ & $3.99[2.88 ; 5.49]$ & $5.73[4.2 ; 7.6]$ & $0.11[0.02 ; 0.47]$ & $0.19[0.09 ; 0.33]$ \\
\hline & & Mixed & $6.74[6.53 ; 6.89]$ & $4.51[4.37 ; 4.66]$ & $4.69[4.47 ; 4.83]$ & $0.06[0.02 ; 0.2]$ & $0.28[0.23 ; 0.32]$ \\
\hline & \multirow{2}{*}{$\begin{array}{l}\text { Difference } \\
\text { (analyzed } \\
\text { ratio: } \\
\text { Mixed/Pure): }\end{array}$} & significance & ns & ns & ns & $*$ & ns \\
\hline & & Magnitude & $\mathrm{nc}$ & nc & $\mathrm{nc}$ & - & nc \\
\hline \multirow{4}{*}{ On pine } & \multirow{2}{*}{ Composition } & Pure & $3.08[1.9 ; 4.88]$ & $1.78[0.98 ; 3.15]$ & $2.38[1.65 ; 3.33]$ & $0.12[0.01 ; 0.66]$ & $0.02[0.004 ; 0.08]$ \\
\hline & & Mixed & $4.42[3.7 ; 5.21]$ & $2.93[2.36 ; 3.63]$ & $3.66[3.56 ; 3.7]$ & $0.04[0.01 ; 0.19]$ & $0.01[0.008 ; 0.02]$ \\
\hline & \multirow{2}{*}{$\begin{array}{c}\text { Difference } \\
\text { (analyzed } \\
\text { ratio: } \\
\text { Mixed/Pure): }\end{array}$} & significance & $*$ & $* *$ & $*$ & $*$ & ns \\
\hline & & Magnitude & + & ++ & + & -- & nc \\
\hline
\end{tabular}

ns $=$ non-significant, $\mathrm{nc}=$ no possible conclusion about effect magnitude, ${ }^{*}=$ significant $(p<0.05),{ }^{* *}=$ significant $(p<0.01),+=$ strong positive effect $($ more than $10 \%$ more species in mixed stands), ++= very strong positive effect (more than $20 \%$ more species in mixed stands).

SRepiph= epiphytic richness; SRground= ground bryophyte richness within $1 \mathrm{~m}$ of the trunk; SRglob=epiphytic and ground richness per tree; ABground= ground bryophyte abundance within $1 \mathrm{~m}$ of the trunk; $\mathrm{N}=$ maximum measured ground bryophyte abundance within $1 \mathrm{~m}$ of the trunk $\left(15,000 \mathrm{~cm}^{2}\right)$; ABepiph=mean epiphyte cover (in percentage of cover 
Table 3. Presence probabilities of the most frequent bryophyte species on oak and pine trees in interaction with stand composition type, estimated through logistic regression (Hypothesis H2). The values here do not include the inter-plot variability (random effects).

\begin{tabular}{|c|c|c|c|c|c|c|c|}
\hline & \multirow[b]{2}{*}{$\begin{array}{l}\text { Number of } \\
\text { occurrences }\end{array}$} & \multicolumn{3}{|c|}{ Presence probability on oak } & \multicolumn{3}{|c|}{ Presence probability on pine } \\
\hline & & in pure stands & in mixed stands & $\begin{array}{l}\text { Pure/mixed } \\
\text { difference }\end{array}$ & in pure stands & in mixed stands & $\begin{array}{l}\text { Pure/mixed } \\
\text { difference }\end{array}$ \\
\hline Campylopus flexuosus (Hedw.) Brid. & 10 & $0.04[0.0004 ; 0.15]$ & $0.01[0.003 ; 0.25]$ & $\mathrm{ns} / \mathrm{nc}$ & $0.00[0.00 ; 0.00]$ & $0.26[0.05 ; 0.63]$ & $\mathrm{ns}(\lim *) /--$ \\
\hline $\begin{array}{l}\text { Lophocolea bidentata (L.) Dumort., } \\
1835\end{array}$ & 9 & $0.07[0.005 ; 0.34]$ & $0.19[0.02 ; 0.57]$ & $\mathrm{ns} / \mathrm{nc}$ & $0.00[0.00 ; 0.00]$ & $0.00[0.00 ; 0.00]$ & $\mathrm{ns} / \mathrm{nc}$ \\
\hline $\begin{array}{l}\text { Lophocolea heterophylla (Schrad.) } \\
\text { Dumort. }\end{array}$ & 24 & $0.16[0.04 ; 0.39]$ & $0.07[0.01 ; 0.25]$ & $\mathrm{ns} / \mathrm{nc}$ & $0.42[0.19 ; 0.67]$ & $0.42[0.21 ; 0.68]$ & $\mathrm{ns} / \mathrm{nc}$ \\
\hline Dicranum scoparium Hedw. & 62 & $1.00[1.00 ; 1.00]$ & $0.85[0.6 ; 0.97]$ & $\mathrm{ns} / \mathrm{nc}$ & $0.21[0.05 ; 0.48]$ & $0.94[0.74 ; 0.99]$ & $* * /--$ \\
\hline Frullania dilatata (L.) Dumort. & 24 & $0.64[0.36 ; 0.88]$ & $0.54[0.26 ; 0.8]$ & $\mathrm{ns} / \mathrm{nc}$ & $0.00[0.00 ; 0.00]$ & $0.00[0.00 ; 0.00]$ & $\mathrm{ns} / \mathrm{nc}$ \\
\hline Frullania tamarisci (L.) Dumort. & 12 & $0.11[0.01 ; 0.43]$ & $0.31[0.06 ; 0.72]$ & $\mathrm{ns} / \mathrm{nc}$ & $0.00[0.00 ; 0.00]$ & $0.00[0.00 ; 0.00]$ & $\mathrm{ns} / \mathrm{nc}$ \\
\hline Hypnum cupressiforme Hedw. & 63 & $1.00[1.00 ; 1.00]$ & $1.00[1.00 ; 1.00]$ & ns/[00] & $0.1[0.01 ; 0.54]$ & $0.84[0.35 ; 0.98]$ & $\mathrm{ns}(\mathrm{lim} *) /--$ \\
\hline $\begin{array}{l}\text { Hypnum jutlandicum Holmen \& } \\
\text { E.Warncke }\end{array}$ & 54 & $0.31[0.11 ; 0.58]$ & $0.42[0.18 ; 0.68]$ & $\mathrm{ns} / \mathrm{nc}$ & $0.89[0.67 ; 0.98]$ & $0.97[0.83 ; 1]$ & $\mathrm{ns} / \mathrm{nc}$ \\
\hline $\begin{array}{l}\text { Leucobryum glaucum (Hedw.) } \\
\text { Angstr. }\end{array}$ & 16 & $0.35[0.12 ; 0.63]$ & $0.11[0.02 ; 0.33]$ & $\mathrm{ns} / \mathrm{nc}$ & $0.00[0.00 ; 0.00]$ & $0.2[0.06 ; 0.46]$ & $\mathrm{ns}\left(\lim ^{*}\right) /--$ \\
\hline Orthotrichum lyellii Hook. \& Taylor & 9 & $0.13[0.01 ; 0.49]$ & $0.11[0.01 ; 0.44]$ & $\mathrm{ns} / \mathrm{nc}$ & $0.00[0.00 ; 0.00]$ & $0.00[0.00 ; 0.00]$ & $\mathrm{ns} / \mathrm{nc}$ \\
\hline $\begin{array}{l}\text { Pleurozium schreberi (Willd. ex } \\
\text { Brid.) Mitt. }\end{array}$ & 15 & $0.15[0.02 ; 0.5]$ & $0.08[0.01 ; 0.35]$ & $\mathrm{ns} / \mathrm{nc}$ & $0.15[0.02 ; 0.52]$ & $0.04[0.003 ; 0.26]$ & $\mathrm{ns} / \mathrm{nc}$ \\
\hline Polytrichum formosum Hedw. & 37 & $1.00[1.00 ; 1.00]$ & $0.65[0.32 ; 0.89]$ & $* * /+$ & $0.02[0 ; 0.17]$ & $0.06[0.006 ; 0.26]$ & $\mathrm{ns} / \mathrm{nc}$ \\
\hline $\begin{array}{l}\text { Pseudoscleropodium purum } \\
\text { (Hedw.) M.Fleisch. }\end{array}$ & 57 & $0.62[0.24 ; 0.91]$ & $0.73[0.32 ; 0.95]$ & $\mathrm{ns} / \mathrm{nc}$ & $1.00[1.00 ; 1.00]$ & $0.46[0.13 ; 0.82]$ & $* * /++$ \\
\hline $\begin{array}{l}\text { Thuidium tamariscinum (Hedw.) } \\
\text { Schimp. }\end{array}$ & 26 & $0.47[0.19 ; 0.75]$ & $0.53[0.25 ; 0.8]$ & $\mathrm{ns} / \mathrm{nc}$ & $0.06[0.006 ; 0.25]$ & $0.11[0.02 ; 0.34]$ & $\mathrm{ns} / \mathrm{nc}$ \\
\hline
\end{tabular}

Pure/Mixed difference: ratio between the presence probability of the species in pure stands and its presence probability in mixed stands. 
$+($ resp. ++ ): non negligible difference in presence probability, with ratio $>1$, negligibility threshold $=10 \%$ (resp. $20 \%)$;

$-($ resp. --$)$ : non negligible difference in presence probability, with ratio $<1$, negligibility threshold $=10 \%$ (resp. $20 \%$ )

00: very negligible difference (threshold $=10 \%) ; 0$ : negligible difference (threshold $=20 \%$ ); $n c$ : no possible conclusion about the magnitude of the difference; $n s:$ non-significant $(p<0.05$ )

*: significant $(\mathrm{p}<.005)^{* *}$ : significant $(\mathrm{p}<0.001)$

The values (means and $95 \%$ confidence intervals) are rounded to two decimal places. 
Table 4. Plot level. Presence probabilities of the most frequent bryophyte species in mixed and pure stands, estimated through logistic regression (Hypothesis H3). The values here do not include the inter-plot variability (random effects)

\begin{tabular}{|c|c|c|c|c|c|c|c|}
\hline \multirow[b]{2}{*}{ Species } & \multirow[b]{2}{*}{$\begin{array}{c}\mathrm{Nb} \\
\text { occurr. }\end{array}$} & \multicolumn{3}{|c|}{ Species presence probability } & \multicolumn{3}{|c|}{ Difference between stands } \\
\hline & & Pure oak stands & Mixed stands & Pure pine stands & $\begin{array}{c}\text { Analyzed } \\
\text { Ratio }\end{array}$ & significance & magnitude \\
\hline \multirow[t]{3}{*}{ Hypnum jutlandicum Holmen \& E.Warncke } & 26 & $0.8[0.29 ; 0.99]$ & $1.00[1.00 ; 1.00]$ & $1.00[1.00 ; 1.00]$ & $\mathrm{M} / \mathrm{O}$ & ns & $\mathrm{nc}$ \\
\hline & & & & & $\mathrm{M} / \mathrm{P}$ & ns & 00 \\
\hline & & & & & $\mathrm{O} / \mathrm{P}$ & ns & $\mathrm{nc}$ \\
\hline \multirow[t]{3}{*}{ Hypnum cupressiforme Hedw. } & 23 & $1.00[1.00 ; 1.00]$ & $1.00[1.00 ; 1.00]$ & $0.2[0.01 ; 0.7]$ & $\mathrm{M} / \mathrm{O}$ & ns & 00 \\
\hline & & & & & $M / P$ & $*$ & ++ \\
\hline & & & & & $\mathrm{O} / \mathrm{P}$ & $*$ & ++ \\
\hline \multirow[t]{3}{*}{ Lophocolea heterophylla (Schrad.) Dumort. } & 17 & $0.41[0.08 ; 0.82]$ & $0.59[0.26 ; 0.87]$ & $0.93[0.53 ; 1]$ & $\mathrm{M} / \mathrm{O}$ & ns & $\mathrm{nc}$ \\
\hline & & & & & $M / P$ & ns & $\mathrm{nc}$ \\
\hline & & & & & $\mathrm{O} / \mathrm{P}$ & ns & - \\
\hline \multirow[t]{3}{*}{ Campylopus flexuosus (Hedw.) Brid. } & 9 & $0.16[0.01 ; 0.74]$ & $0.49[0.09 ; 0.9]$ & $0.00[0.00 ; 0.00]$ & $\mathrm{M} / \mathrm{O}$ & ns & $\mathrm{nc}$ \\
\hline & & & & & $M / P$ & ns (lim) & ++ \\
\hline & & & & & $\mathrm{O} / \mathrm{P}$ & $*$ & ++ \\
\hline \multirow[t]{3}{*}{ Dicranum scoparium Hedw. } & 25 & $1.00[1.00 ; 1.00]$ & $1.00[1.00 ; 1.00]$ & $0.6[0.14 ; 0.95]$ & $\mathrm{M} / \mathrm{O}$ & ns & 00 \\
\hline & & & & & $M / P$ & ns & $\mathrm{Nc}(+)$ \\
\hline & & & & & $\mathrm{O} / \mathrm{P}$ & $*$ & $\mathrm{Nc}(+)$ \\
\hline \multirow[t]{3}{*}{ Frullania dilatata (L.) Dumort. } & 16 & $1.00[1.00 ; 1.00]$ & $0.67[0.31 ; 0.91]$ & $0.00[0.00 ; 0.00]$ & $\mathrm{M} / \mathrm{O}$ & $*$ & - \\
\hline & & & & & $M / P$ & $*$ & ++ \\
\hline & & & & & $\mathrm{O} / \mathrm{P}$ & $*$ & ++ \\
\hline \multirow[t]{3}{*}{ Frullania tamarisci (L.) Dumort. } & 9 & $0.39[0.05 ; 0.87]$ & $0.38[0.07 ; 0.8]$ & $0.00[0.00 ; 0.00]$ & $\mathrm{M} / \mathrm{O}$ & ns & $\mathrm{nc}$ \\
\hline & & & & & $M / P$ & ns & ++ \\
\hline & & & & & $\mathrm{O} / \mathrm{P}$ & $*$ & ++ \\
\hline \multirow[t]{3}{*}{ Leucobryum glaucum (Hedw.) Angstr. } & 12 & $0.94[0.53 ; 1]$ & $0.39[0.09 ; 0.78]$ & $0.00[0.00 ; 0.00]$ & $\mathrm{M} / \mathrm{O}$ & $*$ & - \\
\hline & & & & & $\mathrm{M} / \mathrm{P}$ & ns & 00 \\
\hline & & & & & O/P & $*$ & 00 \\
\hline
\end{tabular}




\begin{tabular}{|c|c|c|c|c|c|c|c|}
\hline Pleurozium schreberi (Willd. ex Brid.) Mitt. & 11 & $0.38[0.05 ; 0.86]$ & $0.28[0.04 ; 0.71]$ & $0.4[0.05 ; 0.89]$ & $\mathrm{M} / \mathrm{O}$ & ns & $\mathrm{nc}$ \\
\hline & & & & & $\mathrm{M} / \mathrm{P}$ & ns & $\mathrm{nc}$ \\
\hline & & & & & $\mathrm{O} / \mathrm{P}$ & ns & $\mathrm{nc}$ \\
\hline \multirow[t]{3}{*}{ Polytrichum formosum Hedw. } & 19 & $1.00[1.00 ; 1.00]$ & $0.85[0.49 ; 0.98]$ & $0.06[0.001 ; 0.5]$ & $\mathrm{M} / \mathrm{O}$ & $*$ & $\mathrm{nc}$ \\
\hline & & & & & $\mathrm{M} / \mathrm{P}$ & ns & ++ \\
\hline & & & & & O/P & $*$ & ++ \\
\hline \multicolumn{8}{|l|}{ Pseudoscleropodium purum (Hedw.) } \\
\hline \multirow[t]{3}{*}{ M.Fleisch. } & 24 & $0.95[0.56 ; 1]$ & $0.86[0.47 ; 0.98]$ & $1.00[1.00 ; 1.00]$ & $\mathrm{M} / \mathrm{O}$ & ns & $\mathrm{nc}$ \\
\hline & & & & & $\mathrm{M} / \mathrm{P}$ & $*$ & $\mathrm{nc}$ \\
\hline & & & & & $\mathrm{O} / \mathrm{P}$ & ns & $\mathrm{nc}$ \\
\hline \multirow[t]{3}{*}{ Thuidium tamariscinum (Hedw.) Schimp. } & 19 & $0.94[0.51 ; 1]$ & $0.86[0.5 ; 0.98]$ & $0.2[0.02 ; 0.71]$ & $\mathrm{M} / \mathrm{O}$ & ns & $\mathrm{nc}$ \\
\hline & & & & & $\mathrm{M} / \mathrm{P}$ & ns & ++ \\
\hline & & & & & $\mathrm{O} / \mathrm{P}$ & $*$ & ++ \\
\hline
\end{tabular}

$\mathrm{M} / \mathrm{O}$ : ratio between the presence probability in mixed stands and in pure oak stands. M/P: ratio between the presence probability in mixed stands and in pure pine stands. O/P: ratio between the presence probability in pure oak stands and in pure pine stands.

$+($ resp. ++ ): non negligible difference in presence probability, with ratio $>1$, negligibility threshold $=10 \%$ (resp. $20 \%$ );

$-($ resp. -- ): non negligible difference in presence probability, with ratio $<1$, negligibility threshold $=10 \%$ (resp. 20\%);

00: very negligible difference (threshold $=10 \%)$; 0 : negligible difference (threshold $=20 \%$ ); $n c$ : no possible conclusion about the magnitude of the difference. $n s$ : non-significant ( $<<0.05$ ) *:

significant $(p<.005)$.

The values (means and $95 \%$ confidence intervals) are rounded to two decimal places. 


\section{Supplementary material}

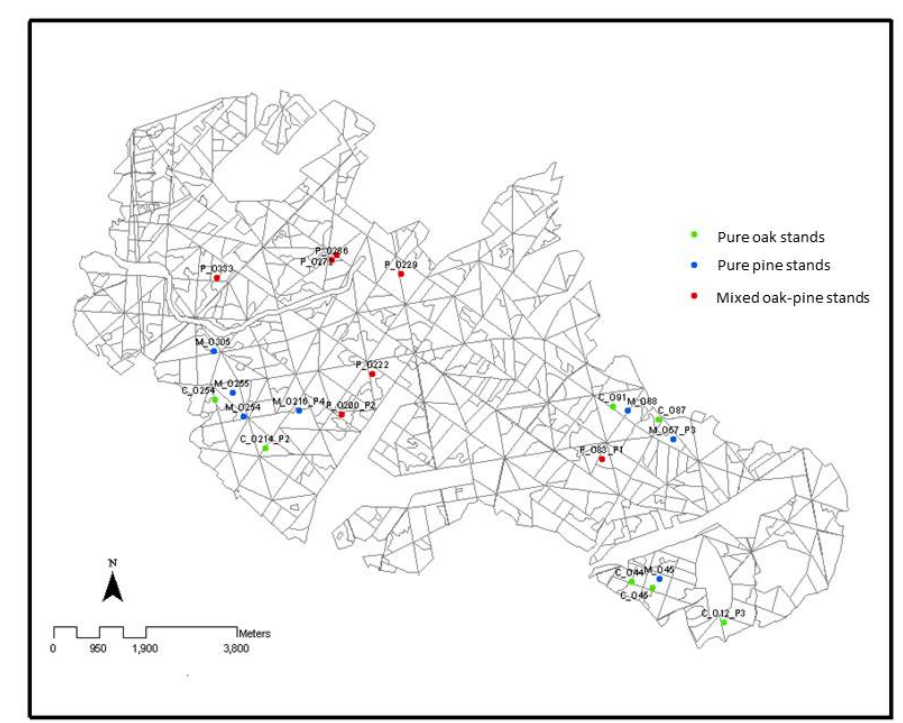

Figure SM1. The study design consisted in seven repetitions for three stand types: pure oak, pure pine and mixed oak-pine stands, leading to a total of 21 plots. 
Table SM1. Tree- and plot-level main and exploratory hypotheses.

\begin{tabular}{|c|c|c|c|c|}
\hline $\begin{array}{l}\text { Hypothesis } \\
\text { Type }\end{array}$ & Level & Tested effects & $\begin{array}{l}\text { Bryophyte diversity } \\
\text { component }\end{array}$ & Hypothesis \\
\hline \multirow{5}{*}{ Main } & \multirow{3}{*}{ Tree } & \multirow[b]{2}{*}{ Tree species $(\mathrm{H} 1)$} & Richness and abundance & $\begin{array}{l}\text { H1a) Bryophyte species diversity (both epiphyte and ground) is higher on oak than on } \\
\text { pine }\end{array}$ \\
\hline & & & Composition & $\begin{array}{l}\text { H1b) Presence probability of bryophyte species (both epiphyte and ground) on and } \\
\text { under a tree differs between oak and pine. }\end{array}$ \\
\hline & & $\begin{array}{l}\text { Interaction between tree } \\
\text { species identity and stand } \\
\text { composition }(\mathrm{H} 2)\end{array}$ & $\begin{array}{l}\text { Richness, abundance and } \\
\text { composition }\end{array}$ & $\begin{array}{l}\text { H2) For a given tree-species, both epiphyte and ground bryophyte diversity differs } \\
\text { between pure and mixed stands. }\end{array}$ \\
\hline & \multirow{2}{*}{ Plot } & \multirow[b]{2}{*}{ Stand composition (H3) } & Richness and abundance & $\begin{array}{l}\text { H3a) The plot species diversity (both epiphyte and ground species) is higher in mixed } \\
\text { stands than in pure ones; this is related to higher habitat heterogeneity. }\end{array}$ \\
\hline & & & Composition & $\begin{array}{l}\mathrm{H} 3 \mathrm{~b}) \text { Presence probability of bryophyte species at the plot level depends on the } \\
\text { composition of the stand (pure pine, pure oak, mixture). }\end{array}$ \\
\hline \multirow{4}{*}{ Exploratory } & \multirow{3}{*}{ Tree } & \multirow{2}{*}{$\begin{array}{l}\text { Substrate and water supply } \\
\text { characteristics }(\mathrm{H} 4)\end{array}$} & $\begin{array}{l}\text { Epiphytic bryophyte } \\
\text { diversity }\end{array}$ & $\begin{array}{l}\text { H4a) Epiphytic bryophyte diversity increases with trunk diameter, with inclination and } \\
\text { with bark and stemflow pH or conductivity. }\end{array}$ \\
\hline & & & $\begin{array}{l}\text { Ground bryophyte } \\
\text { diversity }\end{array}$ & $\begin{array}{l}\text { H4b) Ground bryophyte diversity under the tree varies with trunk diameter and } \\
\text { increases with soil and throughfall } \mathrm{pH} \text { and conductivity. }\end{array}$ \\
\hline & & $\begin{array}{l}\text { Basal area and interfering } \\
\text { plants (H5) }\end{array}$ & Richness and abundance & $\begin{array}{l}\text { H5) Species diversity (both epiphyte and ground) decreases with stand density or } \\
\text { interfering understory plant cover. }\end{array}$ \\
\hline & Plot & $\begin{array}{l}\text { Basal area and interfering } \\
\text { plants }(\mathrm{H} 6)\end{array}$ & Richness and abundance & $\begin{array}{l}\text { H6) Plot species diversity (both epiphyte and ground) decreases with tree density or } \\
\text { interfering understory plant cover; this is related to less light. }\end{array}$ \\
\hline
\end{tabular}


Table SM2. Models used at tree or plot level and corresponding response variables. The main models are those for which the sampling design was balanced. Other models are based on other environmental data used as single explanatory variables or additional covariates.

\begin{tabular}{|c|c|c|c|c|c|c|}
\hline Scale & Hypothesis & $\begin{array}{l}\text { Response } \\
\text { variable }\end{array}$ & Models & $\begin{array}{l}\text { Variable content of the model in R } \\
\text { syntax }\end{array}$ & Covariable & Model type \\
\hline Tree & H1a & $\begin{array}{c}\text { SRepiph } \\
\text { SRground } \\
\text { SRglob } \\
\text { ABground } \\
\text { SRground25 } \\
\text { SRground75 } \\
\text { ABground25 } \\
\text { ABground75 } \\
\text { ABepiph }\end{array}$ & Tree species & $\sim$ Tree_Species -1 & & Main \\
\hline 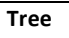 & H1b & Sp.Occurence & Tree_Species & $\sim$ Tree_Species -1 & & Main \\
\hline Tree & $\mathrm{H} 2$ & $\begin{array}{c}\text { SRepiph } \\
\text { SRground } \\
\text { SRglob } \\
\text { ABground } \\
\text { SRground25 } \\
\text { SRground75 } \\
\text { ABground25 } \\
\text { ABground75 } \\
\text { ABepiph } \\
\text { Sp.Occurence } \\
\end{array}$ & Tree_Species:Stand_composition & $\begin{array}{l}\sim \text { ifelse(Compo_MP=="Pure",1,-1): } \\
\text { Tree_Species+ Tree_Species }\end{array}$ & & Main \\
\hline Tree & $\mathrm{H} 4 \mathrm{a}$ & $\begin{array}{l}\text { SRepiph } \\
\text { ABepiph }\end{array}$ & $\begin{array}{l}\text { Tree_Species + Covariable } \\
\text { Covariable } \\
\text { Tree_Species:Stand_composition + } \\
\text { Covariable }\end{array}$ & $\begin{array}{l}\text { Tree_Species + Covariable } \\
\sim \text { Covariable } \\
\sim \text { ifelse(Compo_MP=E"Pure",1,-1): } \\
\text { Tree_Species+Tree_Species + } \\
\text { Covariable }\end{array}$ & $\begin{array}{l}\text { Bark pH } \\
\text { Bark conductivity } \\
\text { Trunk diameter } \\
\text { Trunk Inclination } \\
\text { October stemflow } \\
\text { pH } \\
\text { February } \\
\text { stemflow } \\
\text { conductivity } \\
\end{array}$ & $\begin{array}{l}\text { Exploratory } \\
\text { Exploratory } \\
\text { Exploratory }\end{array}$ \\
\hline \multirow[t]{5}{*}{ Tree } & \multirow[t]{5}{*}{$\mathrm{H} 4 \mathrm{~b}$} & $\begin{array}{l}\text { SRground } \\
\text { ABground } \\
\text { (SRglob) } \\
\text { SRground25 } \\
\text { SRground75 } \\
\text { ABground25 } \\
\text { ABground75 }\end{array}$ & $\begin{array}{l}\text { Tree_Species + Covariable } \\
\text { Covariable } \\
\text { Tree_Species:Stand_composition + } \\
\text { Covariable }\end{array}$ & $\begin{array}{l}\sim \text { Tree_Species + Covariable } \\
\sim \text { Covariable } \\
\sim \text { ifelse(Compo_MP=E="Pure",1,-1): } \\
\text { Tree_Species+Tree_Species + } \\
\text { Covariable }\end{array}$ & Tree diameter & $\begin{array}{l}\text { Exploratory } \\
\text { Exploratory } \\
\text { Exploratory }\end{array}$ \\
\hline & & \multirow{2}{*}{$\begin{array}{l}\text { SRground25 } \\
\text { ABground25 }\end{array}$} & Tree_Species + Covariable & $\sim$ Species + Covariable & \multirow{2}{*}{$\begin{array}{l}\text { pH.TF25.Oct } \\
\text { pH.TF25.Feb } \\
\text { pH.OM.25 } \\
\text { pH.Surf25 } \\
\text { conduc.TF25 }\end{array}$} & Exploratory \\
\hline & & & $\begin{array}{l}\text { Covariable } \\
\text { Tree_Species:Stand_composition + } \\
\text { Covariable }\end{array}$ & $\begin{array}{l}\sim \text { Covariable } \\
\sim \text { ifelse(Compo_MP=="Pure",1,-1): } \\
\text { Tree_Species+ Tree_Species + } \\
\text { Covariable }\end{array}$ & & $\begin{array}{l}\text { Exploratory } \\
\text { Exploratory }\end{array}$ \\
\hline & & \multirow[t]{2}{*}{$\begin{array}{l}\text { SRground75 } \\
\text { ABground75 }\end{array}$} & $\begin{array}{l}\text { Tree_Species + Covariable } \\
\text { Covariable }\end{array}$ & $\begin{array}{l}\sim \text { Tree_Species + Covariable } \\
\sim \sim \text { Covariable }\end{array}$ & \multirow{2}{*}{$\begin{array}{l}\text { pH.TF75.Oct } \\
\text { pH.TF75.Feb } \\
\text { pH.OM.75 } \\
\text { pH.Surf75 }\end{array}$} & $\begin{array}{l}\text { Exploratory } \\
\text { Exploratory }\end{array}$ \\
\hline & & & $\begin{array}{l}\text { Tree_Species:Stand_composition + } \\
\text { Covariable }\end{array}$ & $\begin{array}{l}\sim \text { ifelse(Compo_MP=="Pure",1,-1): } \\
\text { Tree_Species+ Tree_Species + }\end{array}$ & & Exploratory \\
\hline
\end{tabular}




\begin{tabular}{|c|c|c|c|c|c|c|}
\hline & & & & Covariable & conduc.TF75 & \\
\hline \multirow[t]{22}{*}{ Tree } & \multirow[t]{22}{*}{ H5 } & \multirow{8}{*}{$\begin{array}{c}\text { SRepiph } \\
\text { ABepiph } \\
\text { SRground } \\
\text { ABground } \\
\text { SRglob } \\
\text { SRground25 } \\
\text { SRground75 } \\
\text { ABground25 } \\
\text { ABground75 } \\
\end{array}$} & Tree_Species + Covariable & $\sim$ Tree_Species + Covariable & \multirow{8}{*}{$\begin{array}{l}\text { G } \\
\text { G+G^2 } \\
\text { Rec_Interf_Glob }\end{array}$} & Exploratory \\
\hline & & & Covariable & $\sim$ Covariable & & Exploratory \\
\hline & & & Tree_Species:Stand_composition + & ifelse(Compo_MP=="Pure",1,-1): & & Exploratory \\
\hline & & & Covariable & Tree_Species+ Tree_Species + & & \\
\hline & & & & & & \\
\hline & & & & & & \\
\hline & & & & & & \\
\hline & & & & & & \\
\hline & & \multirow{8}{*}{$\begin{array}{c}\text { SRepiph } \\
\text { ABepiph } \\
\text { SRground } \\
\text { ABground } \\
\text { SRglob } \\
\text { SRground25 } \\
\text { SRground75 } \\
\text { ABground25 } \\
\text { ABground75 }\end{array}$} & Tree_Species : Covariable & $\begin{array}{l}\text { Tree_Species + Tree_Species: } \\
\text { Covariable - } 1\end{array}$ & \multirow{8}{*}{$\begin{array}{l}G \\
G+G^{\wedge} 2\end{array}$} & Exploratory \\
\hline & & & Tree_Species : Stand_composition : & Stand_sp_type + & & Exploratory \\
\hline & & & Covariable & Covariable:Stand_sp_type - 1 & & \\
\hline & & & & & & \\
\hline & & & & & & \\
\hline & & & & & & \\
\hline & & & & & & \\
\hline & & & & & & \\
\hline & & \multirow{3}{*}{$\begin{array}{l}\text { SRground25 } \\
\text { ABground25 }\end{array}$} & Tree_Species + Covariable & $\sim$ Tree_Species + Covariable & \multirow[b]{3}{*}{ Rec_Interf_25 } & Exploratory \\
\hline & & & Covariable & $\sim$ Covariable & & Exploratory \\
\hline & & & $\begin{array}{l}\text { Tree_Species:Stand_composition + } \\
\text { Covariable }\end{array}$ & $\begin{array}{l}\text { ifelse(Compo_MP=="Pure",1,-1): } \\
\text { Tree_Species+ Tree_Species + } \\
\text { Covariable }\end{array}$ & & Exploratory \\
\hline & & \multirow{3}{*}{$\begin{array}{l}\text { SRground75 } \\
\text { ABground75 }\end{array}$} & Tree_Species + Covariable & $\sim$ Tree_Species + Covariable & \multirow[b]{3}{*}{ Rec_Interf_75 } & Exploratory \\
\hline & & & Covariable & $\sim$ Covariable & & Exploratory \\
\hline & & & $\begin{array}{l}\text { Tree_Species:Stand_composition + } \\
\text { Covariable }\end{array}$ & $\begin{array}{l}\sim \text { ifelse(Compo_MP=="Pure",1,-1): } \\
\text { Tree_Speciest Tree_Species + } \\
\text { Covariable }\end{array}$ & & Exploratory \\
\hline \multirow[t]{5}{*}{ Plot } & H3a & $\begin{array}{l}\text { SRepiph } \\
\text { SRground } \\
\text { SRglob } \\
\text { ABground }\end{array}$ & Stand composition & $\sim$ Stand_composition & $\begin{array}{l}\mathrm{G} \\
\mathrm{G}+\mathrm{G} \wedge 2 \\
\text { Rec_Interf_Glob }\end{array}$ & Main \\
\hline & $\mathrm{H} 3 \mathrm{~b}$ & Sp.Occurence & Stand_Composition & $\sim$ Stand_Composition - 1 & & Main \\
\hline & \multirow[t]{3}{*}{ H6 } & \multirow{3}{*}{$\begin{array}{l}\text { SRepiph } \\
\text { SRground } \\
\text { SRglob } \\
\text { ABground }\end{array}$} & Covariable & $\sim$ Covariable & \multirow{3}{*}{$\begin{array}{l}G \\
G+G \wedge 2 \\
\text { Rec_Interf_Glob }\end{array}$} & Exploratory \\
\hline & & & Stand_Composition + Covariable & $\sim$ Stand_Composition + Covariable - 1 & & Exploratory \\
\hline & & & Stand_Composition:Covariable & $\begin{array}{l}\sim \text { Stand_composition + Covariable: } \\
\text { Stand composition }-1\end{array}$ & & Exploratory \\
\hline
\end{tabular}

SRepiph = species richness resulting from data collected on trunks. SRground = species richness resulting from data collected on the forest floor within a distance of 1 meter around the trunk. SRglob = species richness resulting from data collected both on the trunk and on the forest floor within a distance of 1 meter around the trunk. ABground: abundance of species collected on the forest floor within a distance of 1 meter around the trunk. SRground25 (resp.ABground25) = species richness (resp. abundance) resulting from data collected on the forest floor at $25 \mathrm{~cm}$ from the trunk. SRground75 (resp.ABground75) $=$ species richness (resp. abundance) resulting from data collected on the forest floor at $75 \mathrm{~cm}$ from the trunk. ABepiph: total abundance of species collected on trunks. Sp.Occurence: presence probability of a bryophyte species.

Tree_Species: 2-level factor (pine or oak). Compo_MP: 2-level factor (pure or mixed). Stand_composition: 3-level factor (oak pure, pine pure, mixture). Stand_sp_type : 4-level factor (oak in pure stands, oak in mixed stands, pine in pure stands, pine in mixed stands). Diameter: mean quadratic diameter at 1.3m height. Inclination: trunk inclination (angle from the vertical, in degrees). Bark.pH: measured bark pH. Bark.conduc: measured bark conductivity. pH.TF25. Oct (resp. pH.TF75.Oct): measured pH of throughfall samplings collected in October at $25 \mathrm{~cm}$ (resp. $75 \mathrm{~cm}$ ) from the trunk. pH.TF25.Feb (resp. pH.TF75.Feb): measured pH of throughfall samplings collected in February at $25 \mathrm{~cm}$ (resp. $75 \mathrm{~cm}$ ) from the trunk. Conduc.TF25 (resp. conduc.TF75): measured conductivity of throughfall samplings collected in February at $25 \mathrm{~cm}$ (resp. $75 \mathrm{~cm}$ ) from the trunk. pH.OM. 25 (resp. pH.OM.75): measured pH of the organo-mineral horizon samples collected at $25 \mathrm{~cm}$ (resp. $75 \mathrm{~cm}$ ) from the trunk. pH.Surf25 (resp. pH.Surf75): measured pH of the surface soil samples 
collected at $25 \mathrm{~cm}$ (resp. $75 \mathrm{~cm}$ ) from the trunk. G: basal area of the plot $\left(\mathrm{m}^{2} \mathrm{ha}^{-1}\right)$. Rec_Interf_25 (resp. Rec_Interf_75): Cover percentage of interfering vegetation within a $50 \mathrm{~cm}$-width ring centered $25 \mathrm{~cm}$ (resp. 75 $\mathrm{cm}$ ) from the trunk. Rec_Interf_Glob : cover percentage of interfering vegetation inside a ring 1 meter in width traced around the trunk. 
Table SM3. Notations for the magnitude of the effect. A strong effect leads to a variation of more than $10 \%$ in the response variable, a very strong effect leads to a variation of more than $20 \%$. Note that $\beta \Delta X$ is equal to $\log \left(\operatorname{mean}\left(\mathrm{Y}_{\text {new }}\right) /\right.$ mean $\left.\left(\mathrm{Y}_{\text {init }}\right)\right)$, where $\mathrm{Y}_{\text {new }}$ is the modeled response random variable after the simulated variation $\Delta \mathrm{X}$ of the explanatory variable, and $\mathrm{Y}_{\text {init }}$ is the response random variable for the initial value of $\mathrm{X}$.

\begin{tabular}{|c|c|c|c|}
\hline Version & $\begin{array}{l}\text { Case } \\
\text { (In this example, the response random variable } Y \text { is count data, modelled by } \\
\text { mean }(Y)=\exp (\alpha+\beta X) . X \text { is the explanatory variable and } \Delta X \text { the simulated } \\
\text { variation in } X) \text {. }\end{array}$ & Notation & Meaning \\
\hline \multirow[t]{4}{*}{ weak } & $\mathrm{P}(\log (0.9)<\beta \Delta \mathrm{X}<\log (1.1)) \geq 95 \%$ & 00 & Very negligible effect \\
\hline & $P(\beta \Delta X>\log (1.1)) \geq 95 \%$ & + & Strong positive effect \\
\hline & $\mathrm{P}(\beta \Delta \mathrm{X}<\log (0.9)) \geq 95 \%$ & - & Strong negative effect \\
\hline & Other cases & nc & No possible conclusion \\
\hline \multirow[t]{4}{*}{ strong } & $\mathrm{P}(\log (0.8)<\beta \Delta \mathrm{X}<\log (1.2)) \geq 95 \%$ & 0 & Negligible effect \\
\hline & $P(\beta \Delta X>\log (1.2)) \geq 95 \%$ & ++ & $\begin{array}{l}\text { Very strong positive } \\
\text { effect }\end{array}$ \\
\hline & $\mathrm{P}(\beta \Delta \mathrm{X}<\log (0.8)) \geq 95 \%$ & -- & $\begin{array}{l}\text { Very strong negative } \\
\text { effect }\end{array}$ \\
\hline & Other cases & $\mathrm{nc}$ & No possible conclusion \\
\hline
\end{tabular}


Table SM4. List of bryophyte species recorded during the study (21 bryophytes, 8 liverworts in bold). Code $=$ abbreviated name. Nb occur. $=$ number of occurrences in our dataset at tree level. Species = scientific names following Gargominy et al.'s (2015) nomenclature.

\begin{tabular}{|c|c|c|c|c|c|}
\hline Code & Name & $\mathrm{Nb}$ occur. & Oak only & Pine only & Oak and pine \\
\hline BRARUT & Brachythecium rutabulum (Hedw.) Schimp. & 3 & $x$ & & \\
\hline BRYCAP & Ptychostomum capillare (Hedw.) Holyoak \& N. Pedersen & 1 & $\mathrm{x}$ & & \\
\hline CAMFLE & Campylopus flexuosus (Hedw.) Brid. & 24 & & & $\mathrm{x}$ \\
\hline CAMINT & Campylopus introflexus (Hedw.) Brid. & 1 & $\mathrm{x}$ & & \\
\hline DICHET & Dicranella heteromalla (Hedw.) Schimp. & 7 & & & $\mathrm{x}$ \\
\hline DICMON & Dicranum montanum Hedw. & 3 & & $x$ & \\
\hline DICSCOP & Dicranum scoparium Hedw. & 223 & & & $x$ \\
\hline EURSTR & Eurhynchium striatum (Hedw.) Schimp. & 12 & $\mathrm{x}$ & & \\
\hline FRUDIL & Frullania dilatata (L.) Dumort. & 24 & $\mathbf{x}$ & & \\
\hline FRUTAM & Frullania tamarisci (L.) Dumort. & 16 & $\mathbf{x}$ & & \\
\hline HYPAND & Hypnum andoi A.J.E.Sm. & 1 & $x$ & & \\
\hline HYPCUP & Hypnum cupressiforme Hedw. & 213 & & & $x$ \\
\hline HYPJUT & Hypnum jutlandicum Holmen \& E.Warncke & 185 & & & $\mathrm{x}$ \\
\hline ISOALO & Isothecium alopecuroides (Lam. ex Dubois) Isov. & 9 & $\mathrm{x}$ & & \\
\hline ISOMYO & Isothecium myosuroides Brid., 1827 & 5 & $\mathrm{x}$ & & \\
\hline LEUGLA & Leucobryum glaucum (Hedw.) Angstr. & 26 & & & $x$ \\
\hline LOPBID & Lophocolea bidentata (L.) Dumort., 1835 & 18 & $\mathbf{x}$ & & \\
\hline LOPHET & Lophocolea heterophylla (Schrad.) Dumort. & 26 & & & $\mathbf{x}$ \\
\hline METFUR & Metzgeria furcata (L.) Dumort. & 1 & $\mathbf{x}$ & & \\
\hline ORTLYE & Orthotrichum lyellii Hook. \& Taylor & 9 & $x$ & & \\
\hline ORTSTRIA & Orthotrichum striatum Hedw. & 1 & $x$ & & \\
\hline PLASUC & Plagiothecium succulentum (Wilson) Lindb. & 1 & & $x$ & \\
\hline PLESCH & Pleurozium schreberi (Willd. ex Brid.) Mitt. & 28 & & & $x$ \\
\hline POLFOR & Polytrichum formosum Hedw. & 93 & & & $\mathrm{x}$ \\
\hline RADCOM & Radula complanata (L.) Dumort. & 3 & $\mathbf{x}$ & & \\
\hline
\end{tabular}




\begin{tabular}{llccc}
\hline RHYTRI & Rhytidiadelphus triquetrus (Hedw.) Warnst. & 1 & $x$ & \\
\hline SCLPUR & Pseudoscleropodium purum (Hedw.) M.Fleisch. & 222 & & \\
\hline THUTAM & Thuidium tamariscinum (Hedw.) Schimp. & 72 & $\mathrm{x}$ \\
\hline ULOBRU & Ulota bruchii Hornsch. Ex Brid. & 6 & $\mathrm{x}$ \\
\hline ULOsp & Ulota sp. & 2 & \\
\hline
\end{tabular}


Table SM 5. Descriptive statistics of mean species richness per tree, on trunks and on the soil within a distance of $1 \mathrm{~m}$ from the trunk: mean species richness, standard deviation, minimum and maximum values.

\begin{tabular}{|c|c|c|c|c|c|c|}
\hline & Tree species & Mixture type & Mean & sd & $\min$ & $\max$ \\
\hline \multirow{4}{*}{$\begin{array}{l}\text { Number of species on } \\
\text { trunk per tree }\end{array}$} & pine & pure & 1.81 & 0.87 & 1 & 4 \\
\hline & & mixed & 3.05 & 1.07 & 1 & 5 \\
\hline & oak & pure & 4.28 & 1.58 & 2 & 7 \\
\hline & & mixed & 4.28 & 1.58 & 2 & 7 \\
\hline \multirow{4}{*}{$\begin{array}{l}\text { Number of species on } \\
\text { ground per tree }\end{array}$} & pine & pure & 2.42 & 1.07 & 1 & 5 \\
\hline & & mixed & 3.76 & 1.3 & 1 & 7 \\
\hline & oak & pure & 5.85 & 1.74 & 4 & 10 \\
\hline & & mixed & 4.76 & 2.38 & 1 & 12 \\
\hline \multirow{4}{*}{$\begin{array}{l}\text { Abundance of ground } \\
\text { species (cover in } \mathrm{cm}^{2} \text { ) }\end{array}$} & pine & pure & 1761 & 2068 & 128 & 6975 \\
\hline & & mixed & 602 & 396 & 2 & 1464 \\
\hline & oak & pure & 1639 & 872 & 410 & 3823 \\
\hline & & mixed & 990 & 671 & 160 & 2169 \\
\hline
\end{tabular}


Table SM 6. Descriptive statistics of exploratory variables (mean values, standard deviation, minimum and maximum values).

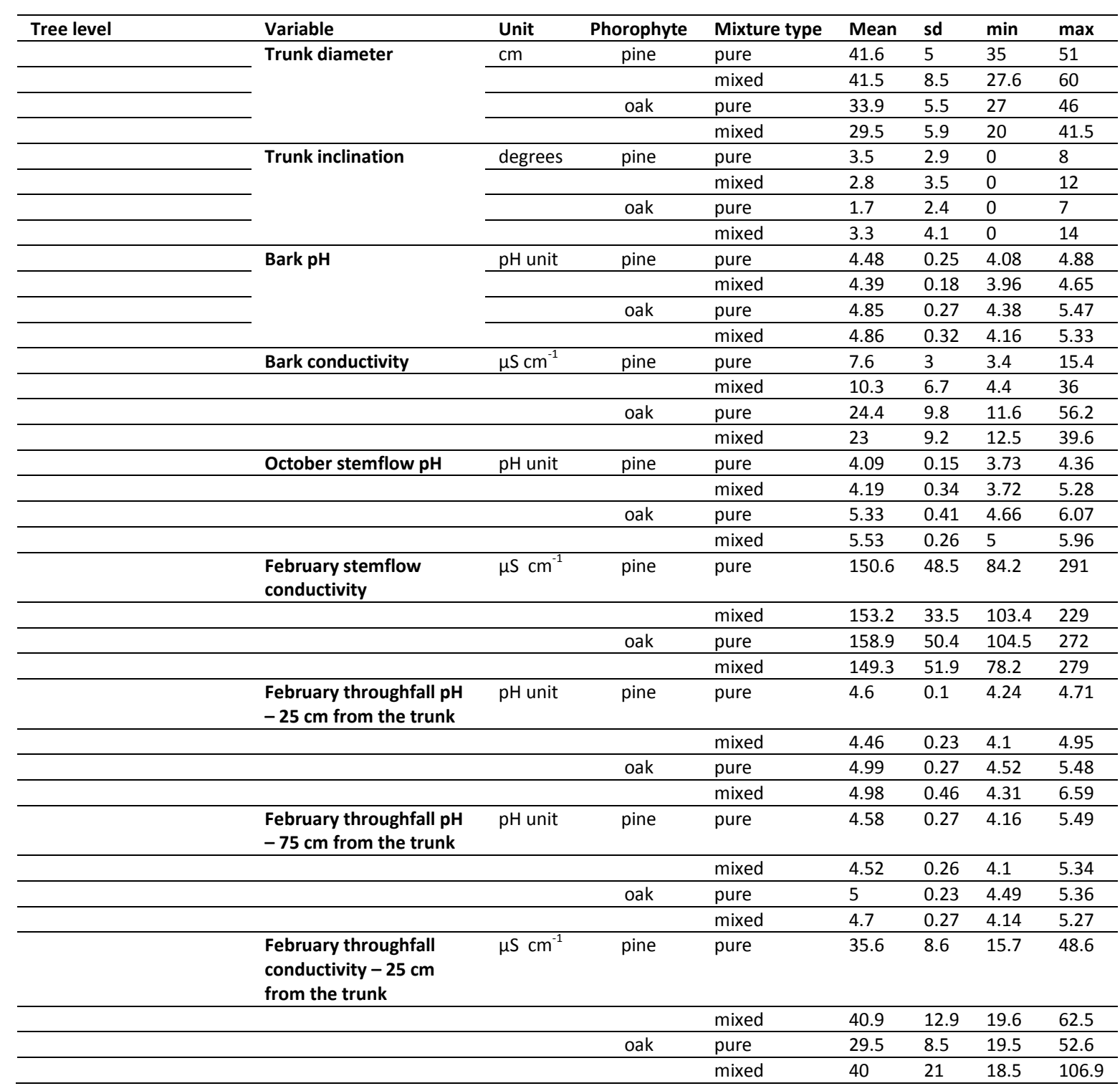




\begin{tabular}{|c|c|c|c|c|c|c|c|}
\hline $\begin{array}{l}\text { February throughfall } \\
\text { conductivity }-75 \mathrm{~cm} \\
\text { from the trunk }\end{array}$ & $\mu \mathrm{S} \mathrm{cm}^{-1}$ & pine & pure & 33.5 & 8.9 & 16.8 & 50.2 \\
\hline & & & mixed & 40 & 12 & 17.9 & 61.8 \\
\hline & & oak & pure & 25.9 & 6.7 & 17.4 & 46.7 \\
\hline & & & mixed & 33.1 & 13.7 & 18.3 & 66.5 \\
\hline $\begin{array}{l}\text { October throughfall pH - } \\
25 \mathrm{~cm} \text { from the trunk }\end{array}$ & $\mathrm{pH}$ unit & pine & pure & 5.17 & 0.41 & 4.61 & 5.98 \\
\hline & & & mixed & 5.06 & 0.33 & 4.45 & 6.05 \\
\hline & & oak & pure & 5.45 & 0.24 & 4.95 & 5.89 \\
\hline & & & mixed & 5.47 & 0.48 & 4.81 & 7.04 \\
\hline $\begin{array}{l}\text { October throughfall pH - } \\
75 \mathrm{~cm} \text { from the trunk }\end{array}$ & $\mathrm{pH}$ unit & pine & pure & 5.04 & 0.25 & 4.51 & 5.53 \\
\hline & & & mixed & 5.19 & 0.44 & 4.1 & 6.15 \\
\hline & & oak & pure & 5.54 & 0.32 & 5.16 & 6.27 \\
\hline & & & mixed & 5.37 & 0.33 & 4.72 & 5.98 \\
\hline $\begin{array}{l}\text { Soil surface } \mathrm{pH}-25 \mathrm{~cm} \\
\text { from the trunk }\end{array}$ & $\mathrm{pH}$ unit & pine & pure & 4.31 & 0.45 & 3.41 & 5.45 \\
\hline & & & mixed & 4.33 & 0.55 & 3.86 & 6.34 \\
\hline & & oak & pure & 4.55 & 0.42 & 4.17 & 6 \\
\hline & & & mixed & 4.38 & 0.29 & 3.92 & 5.3 \\
\hline $\begin{array}{l}\text { Soil surface } \mathrm{pH}-75 \mathrm{~cm} \\
\text { from the trunk }\end{array}$ & $\mathrm{pH}$ unit & pine & pure & 4.53 & 0.52 & 3.95 & 5.79 \\
\hline & & & mixed & 4.24 & 0.17 & 3.99 & 4.59 \\
\hline & & oak & pure & 4.68 & 0.65 & 4.15 & 6.68 \\
\hline & & & mixed & 4.27 & 0.26 & 3.85 & 4.78 \\
\hline $\begin{array}{l}\text { Soil OM pH }-25 \mathrm{~cm} \text { from } \\
\text { the trunk }\end{array}$ & $\mathrm{pH}$ unit & pine & pure & 4.09 & 0.5 & 3.48 & 6.09 \\
\hline & & & mixed & 4.01 & 0.18 & 3.85 & 4.65 \\
\hline & & oak & pure & 4.36 & 0.33 & 3.81 & 5.17 \\
\hline & & & mixed & 4.24 & 0.57 & 3.87 & 6.25 \\
\hline $\begin{array}{l}\text { Soil OM pH }-75 \mathrm{~cm} \text { from } \\
\text { the trunk }\end{array}$ & $\mathrm{pH}$ unit & pine & pure & 4.04 & 0.16 & 3.77 & 4.35 \\
\hline & & & mixed & 4.05 & 0.12 & 3.88 & 4.26 \\
\hline & & oak & pure & 4.31 & 0.33 & 3.76 & 5.03 \\
\hline & & & mixed & 4.02 & 0.17 & 3.74 & 4.41 \\
\hline $\begin{array}{l}\text { Interfering plant cover - } \\
25 \mathrm{~cm} \text { from the trunk }\end{array}$ & $\%$ & pine & pure & 54 & 22 & 2 & 95 \\
\hline & & & mixed & 16 & 17 & 0 & 54 \\
\hline & & oak & pure & 14 & 16 & 0 & 62 \\
\hline & & & mixed & 15 & 14 & 0 & 59 \\
\hline $\begin{array}{l}\text { Interfering plant cover - } \\
75 \mathrm{~cm} \text { from the trunk }\end{array}$ & $\%$ & pine & pure & 64 & 14 & 34 & 89 \\
\hline & & & mixed & 23 & 21 & 0 & 59.5 \\
\hline
\end{tabular}




\begin{tabular}{|c|c|c|c|c|c|c|c|c|}
\hline & & & oak & pure & 12 & 15 & 0 & 47 \\
\hline & & & & mixed & 19 & 13 & 0 & 38 \\
\hline \multirow[t]{6}{*}{ Stand level } & Stand basal area & $m^{2} h a^{-1}$ & \multicolumn{2}{|c|}{ Pure oak stands } & 22.3 & 2.17 & 18.3 & 25.1 \\
\hline & & & \multicolumn{2}{|c|}{ Pure pine stands } & 29 & 6.9 & 19.4 & 40.3 \\
\hline & & & \multicolumn{2}{|c|}{ Mixed stands } & 31.5 & 5.7 & 23.9 & 38.4 \\
\hline & Interfering plant cover & $\%$ & \multicolumn{2}{|c|}{ Pure oak stands } & 17 & 14 & 4 & 43 \\
\hline & & & \multicolumn{2}{|c|}{ Pure pine stands } & 60 & 10 & 45 & 76 \\
\hline & & & \multicolumn{2}{|c|}{ Mixed stands } & 19 & 13 & 0 & 40 \\
\hline
\end{tabular}


Table SM 7. Mean estimated species richness and abundance values on oak and pine, with their $95 \%$ confidence intervals, and analysis of the oak-pine difference (Hypothesis H1). The values here do not include the inter-plot variability (random effects)

\begin{tabular}{|c|c|c|c|c|c|c|}
\hline Tree level & & $\begin{array}{l}\text { SRglob } \\
(n=84) \\
\end{array}$ & $\begin{array}{l}\text { SRepiph } \\
(n=84)\end{array}$ & $\begin{array}{c}\text { SRground } \\
(n=84)\end{array}$ & $\begin{array}{c}\text { ABground/N } \\
(n=84)\end{array}$ & $\begin{array}{c}\text { ABepiph } \\
(n=84)\end{array}$ \\
\hline \multirow{2}{*}{ Tree species } & Pine & $3.84[3.15 ; 4.71]$ & $2.38[1.89 ; 2.97]$ & $3.09[2.46 ; 3.91]$ & $0.07[0.04 ; 0.11]$ & $0.01[0.009 ; 0.02]$ \\
\hline & Oak & $6.55[5.27 ; 7.85]$ & $3.99[3.12 ; 4.85]$ & $4.98[3.84 ; 6.15]$ & $0.09[0.06 ; 0.15]$ & $0.25[0.19 ; 0.33]$ \\
\hline \multirow{2}{*}{$\begin{array}{c}\text { Difference } \\
\text { (analyzed ratio: } \\
\text { SRpine/SRoak) }\end{array}$} & Significance & $* *$ & $* *$ & $* *$ & $*$ & $* *$ \\
\hline & Magnitude & -- & -- & -- & $\mathrm{nc}$ & -- \\
\hline
\end{tabular}

${ }^{* *}=$ significant $(p<0.01),{ }^{*}=$ significant $(p<0.05),--=$ very strong negative effect (decrease of more than $20 \%$ in species or $\mathrm{cm}{ }^{2}$ on pine), nc: no conclusion. 
Table SM 8. Marginalized DIC values for models at tree level. The two first rows give the marginalized DIC for the two main models. Following rows concern exploratory models. For each response variable in the column, the best model corresponds to the lowest DIC value (greyed cells). The sign "-" means "irrelevant".

\begin{tabular}{|c|c|c|c|c|c|c|c|c|c|}
\hline & $\begin{array}{l}\text { SRepiph } \\
(n=71)\end{array}$ & $\begin{array}{l}\text { SRground } \\
(n=84)\end{array}$ & $\begin{array}{l}\text { SRground25 } \\
(\mathrm{n}=78)\end{array}$ & $\begin{array}{l}\text { SRground75 } \\
(\mathrm{n}=81)\end{array}$ & $\begin{array}{l}\text { SRglob } \\
(\mathrm{n}=84)\end{array}$ & $\begin{array}{l}\text { ABground } \\
(n=84)\end{array}$ & $\begin{array}{l}\text { ABground25 } \\
(n=78)\end{array}$ & $\begin{array}{l}\text { ABground75 } \\
(\mathrm{n}=81)\end{array}$ & $\begin{array}{l}\text { ABepiph } \\
(\mathrm{n}=71)\end{array}$ \\
\hline Tree species & 246.6128 & 329.5329 & 285.9509 & 307.6195 & 348.6007 & 1382.033 & 1203.622 & 1084.623 & 135.6862 \\
\hline Tree species: Stand_composition & 241.1881 & 320.8182 & 275.037 & 311.1888 & 343.0812 & 1375.811 & 1203.072 & 1080.115 & 137.9688 \\
\hline Tree species + diameter & 247.462 & 329.3704 & 282.4924 & 309.2575 & 348.8818 & 1374.875 & 1206.741 & 1083.84 & 138.7513 \\
\hline $\begin{array}{l}\text { Tree species : Stand_composition } \\
\text { + diameter }\end{array}$ & 240.4589 & 319.2333 & 274.4461 & 312.8724 & 341.88 & 1374.316 & 1208.817 & 1079.027 & 142.8075 \\
\hline Diameter & 273.7516 & 361.415 & 308.4155 & 315.4372 & 394.7232 & 1375.058 & 1207.218 & 1083.489 & 217.9436 \\
\hline Tree species + Inclination & 248.6265 & - & - & - & - & - & - & - & 136.5563 \\
\hline $\begin{array}{l}\text { Tree species : Stand_composition } \\
+ \text { Inclination }\end{array}$ & 240.8859 & - & - & - & - & - & - & - & 141.2402 \\
\hline Inclination & 273.2961 & - & - & - & - & - & - & - & 236.1879 \\
\hline Tree species + bark pH & 245.9701 & - & - & - & - & - & - & - & 139.5103 \\
\hline $\begin{array}{l}\text { Tree species : Stand_composition } \\
\text { + bark pH }\end{array}$ & 236.527 & - & - & - & - & - & - & - & 142.38 \\
\hline Bark pH & 253.0802 & - & - & - & - & - & - & - & 213.7892 \\
\hline Tree species + bark conductivity & 250.6488 & - & - & - & - & - & - & - & 137.3931 \\
\hline $\begin{array}{l}\text { Tree species : Stand_composition } \\
\text { + bark conductivity }\end{array}$ & 241.1134 & - & - & - & - & - & - & - & 140.4444 \\
\hline Bark conductivity & 266.6219 & - & - & - & - & - & - & - & 202.675 \\
\hline $\mathrm{G}$ & 290.488 & 365.7751 & 310.611 & 319.1584 & 405.2095 & 1393.525 & 1221.3 & 1084.73 & 235.4274 \\
\hline$G+G^{\wedge} 2$ & 281.7078 & 370.275 & 311.0587 & 320.1454 & 405.0296 & 1376.229 & 1207.141 & 1088.959 & 237.9216 \\
\hline Tree species + G & 242.83 & 330.6584 & 289.0151 & 309.0797 & 350.9077 & 1377.168 & 1205.519 & 1089.478 & 133.2547 \\
\hline Tree species + G + G^2 & 234.7218 & 333.2187 & 290.1662 & 309.2801 & 355.0115 & 1381.548 & 1198.805 & 1091.329 & 136.1485 \\
\hline $\begin{array}{l}\text { Tree species : Stand_composition } \\
+\mathrm{G}\end{array}$ & 242.8979 & 325.2636 & 277.6279 & 313.2523 & 349.1779 & 1376.837 & 1204.88 & 1080.014 & 139.6016 \\
\hline $\begin{array}{l}\text { Tree species : Stand_composition } \\
+G+G^{\wedge} 2\end{array}$ & 231.6277 & 325.31 & 279.1284 & 314.0015 & 342.7478 & 1379.299 & 1203.973 & 1083.228 & 140.9286 \\
\hline Tree species: G & 243.9205 & 327.6824 & 284.795 & 311.141 & 347.7326 & 1374.371 & 1197.892 & 1083.67 & 135.4038 \\
\hline Tree species : $\left(\mathbf{G}+G^{\wedge} 2\right)$ & 234.8344 & 326.833 & 287.6842 & 310.3945 & 343.7358 & 1398.013 & 1201.381 & 1090.281 & 139.869 \\
\hline Tree species:Compo :G & 238.3853 & 324.3939 & 282.4791 & 314.7519 & 340.762 & 1369.954 & 1205.06 & 1064.625 & 148.9925 \\
\hline Tree species:Compo:(G+ G^2) & 232.7007 & 329.7672 & 287.5461 & 321.8711 & 347.864 & 1373,347 & 1212.891 & 1067.121 & 158.1981 \\
\hline $\begin{array}{l}\text { Tree species + October stemflow } \\
\mathrm{pH}\end{array}$ & 244.7375 & - & - & - & - & - & - & - & 140.6675 \\
\hline $\begin{array}{l}\text { Tree species : Stand_composition } \\
\text { + October stemflow pH }\end{array}$ & 240.4682 & - & - & - & - & - & - & - & 141.0112 \\
\hline October stemflow pH & 244.5123 & - & - & - & - & - & - & - & 170.4704 \\
\hline February stemflow $\mathrm{pH}$ & 257.6953 & - & - & - & - & - & - & - & 175.1187 \\
\hline $\begin{array}{l}\text { Tree species + February stemflow } \\
\text { conductivity }\end{array}$ & - & - & - & - & - & - & - & - & 137.7916 \\
\hline
\end{tabular}




\begin{tabular}{|c|c|c|c|c|c|c|c|c|c|}
\hline $\begin{array}{l}\text { Tree species : Stand_composition } \\
+ \text { February stemflow conductivity }\end{array}$ & - & - & - & - & - & - & - & - & 137.9571 \\
\hline February stemflow conductivity & - & - & - & - & - & - & - & - & 234.5286 \\
\hline $\begin{array}{l}\text { Tree species + Rec_Interf_Glob } \\
\text { (or } 25 \text { or } 75 \text { ) }\end{array}$ & 246.9127 & 328.8958 & 282.9757 & 309.8029 & 348.7878 & 1380.924 & 1206.838 & 1088.29 & 137.0244 \\
\hline $\begin{array}{l}\text { Tree species : Stand_composition } \\
+ \text { Rec_Interf_Glob(or } 25 \text { or } 75 \text { ) }\end{array}$ & 238.5542 & 270.4887 & 278.1338 & 313.9323 & 341.7483 & 1376.635 & 1206.519 & 1078.95 & 139.6359 \\
\hline Rec_Interf_Glob(or 25 or 75 ) & 264.1685 & 346.0743 & 292.9108 & 314.4641 & 386.6704 & 1383.865 & 1208.267 & 1089.428 & 228.9618 \\
\hline $\begin{array}{l}\text { Tree species + October } \\
\text { throughfall pH at } 25 / 75 \mathrm{~cm}\end{array}$ & - & - & 288.7395 & 309.4676 & - & - & 1205.979 & 1084.967 & \\
\hline $\begin{array}{l}\text { Tree species : Stand_composition } \\
+ \text { October throughfall pH at } 25 / 75 \\
\mathrm{~cm}\end{array}$ & - & - & 278.7437 & 312.7931 & - & - & 1206.459 & 1077.787 & \\
\hline $\begin{array}{l}\text { October throughfall } \mathrm{pH} \text { at } 25 / 75 \\
\mathrm{~cm}\end{array}$ & - & - & 315.5185 & 319.8461 & - & - & 1210.012 & 1082.211 & \\
\hline $\begin{array}{l}\text { Tree species + February } \\
\text { throughfall pH at } 25 / 75 \mathrm{~cm}\end{array}$ & - & - & 287.5883 & 303.4898 & - & - & 1200.228 & 1069.704 & \\
\hline $\begin{array}{l}\text { Tree species : Stand_composition } \\
+ \text { February throughfall pH at } \\
25 / 75 \mathrm{~cm}\end{array}$ & - & - & 276.605 & 304.8738 & - & - & 1203.304 & 1053.174 & \\
\hline $\begin{array}{l}\text { February throughfall pH at } 25 / 75 \\
\mathrm{~cm}\end{array}$ & - & - & 301.4618 & 305.8914 & - & - & 1200.757 & 1070.64 & \\
\hline $\begin{array}{l}\text { Tree species }+ \text { organomineral } \\
\text { horizon } \mathrm{pH} \text { at } 25 / 75 \mathrm{~cm}\end{array}$ & - & - & 284.7572 & 309.3773 & - & - & 1204.571 & 1086.317 & \\
\hline $\begin{array}{l}\text { Tree species : Stand_composition } \\
+ \text { organo-mineral horizon } \mathrm{pH} \text { at } 25 \\
\mathrm{~cm}\end{array}$ & - & - & 272.8443 & 312.7839 & - & - & 1202.727 & 1080.393 & \\
\hline $\begin{array}{l}\text { Organo-mineral horizon } \mathrm{pH} \text { at } \\
25 / 75 \mathrm{~cm}\end{array}$ & - & - & 319.0061 & 317.6215 & - & - & 1207.859 & 1083.853 & \\
\hline $\begin{array}{l}\text { Tree species + soil surface } \mathrm{pH} \text { at } \\
25 / 75 \mathrm{~cm}\end{array}$ & - & - & 288.7372 & 309.3372 & - & - & 1204.283 & 1086.29 & \\
\hline $\begin{array}{l}\text { Tree species: Stand_composition } \\
\text { + soil surface } \mathrm{pH} \text { at } 25 / 75 \mathrm{~cm}\end{array}$ & - & - & 277.1499 & 313.7613 & - & - & 1203.496 & 1079.117 & \\
\hline soil surface $\mathrm{pH}$ at $25 / 75 \mathrm{~cm}$ & - & - & 312.5959 & 319.3124 & - & - & 1209.666 & 1083.751 & \\
\hline $\begin{array}{l}\text { Tree species + February } \\
\text { throughfall conductivity at } 25 / 75 \\
\mathrm{~cm}\end{array}$ & - & - & 287.1121 & 301.4843 & - & - & 1202.216 & 1077.073 & \\
\hline $\begin{array}{l}\text { Tree species: Stand_composition } \\
+ \text { + February throughfall } \\
\text { conductivity at } 25 / 75 \mathrm{~cm}\end{array}$ & - & - & 276.7498 & 302.3266 & - & - & 1208.678 & 1075.363 & \\
\hline $\begin{array}{l}\text { February throughfall conductivity } \\
\text { at } 25 / 75 \mathrm{~cm}\end{array}$ & - & - & 317.4102 & 305.9008 & - & - & 1212.285 & 1079.034 & \\
\hline
\end{tabular}


Table SM 9. Effects of stand composition type on bryophyte diversity at plot level (group of three trees) - Hypothesis H3.

\begin{tabular}{|c|c|c|c|c|c|c|}
\hline Plot level - Compositic & 1 effect & $\begin{array}{c}\text { SRepiph } \\
(\mathrm{n}=28)\end{array}$ & $\begin{array}{l}\text { SRground } \\
(\mathrm{n}=28)\end{array}$ & $\begin{array}{l}\text { SRglob } \\
(\mathrm{n}=28)\end{array}$ & $\begin{array}{c}\text { ABground/N } \\
(n=28)\end{array}$ & $\begin{array}{c}\text { ABepiph } \\
(\mathrm{n}=28)\end{array}$ \\
\hline \multirow{3}{*}{ Composition } & Pure Pine $(P)$ & $2.91[1.99 ; 4.18]$ & $4.22[2.94 ; 5.93]$ & $5.18[3.71 ; 7.02]$ & $0.1[0.04 ; 0.28]$ & $0.05[0.02 ; 0.11]$ \\
\hline & Pure Oak (O) & $7.23[5.52 ; 9.31]$ & $9.67[7.29 ; 12.51]$ & $12.51[9.58 ; 15.82]$ & $0.1[0.03 ; 0.24]$ & $0.31[0.2 ; 0.46]$ \\
\hline & Mixture (M) & $7.28[5.8 ; 9.03]$ & $8.37[6.44 ; 10.48]$ & $11.13[8.72 ; 13.65]$ & $0.05[0.01 ; 0.12]$ & $0.21[0.14 ; 0.32]$ \\
\hline \multirow{2}{*}{$\begin{array}{l}\text { Oak-Pine difference } \\
\text { (analyzed ratio: } \mathrm{O} / \mathrm{P} \text { ) }\end{array}$} & Significance & $* *$ & $* *$ & $* *$ & ns & $* *$ \\
\hline & Magnitude & ++ & ++ & ++ & nc & ++ \\
\hline \multirow{2}{*}{$\begin{array}{l}\text { Mixture-Pine difference } \\
\text { (analyzed ratio: } \mathrm{M} / \mathrm{P} \text { ) }\end{array}$} & Significance & $* *$ & $* *$ & $* *$ & ns & $* *$ \\
\hline & Magnitude & ++ & ++ & ++ & nc & ++ \\
\hline \multirow{2}{*}{$\begin{array}{c}\text { Mixture-Oak difference } \\
\text { (analyzed ratio : M/O) }\end{array}$} & Significance & ns & ns & ns & $*$ & ns \\
\hline & Magnitude & $\mathrm{nc}$ & nc & nc & -- & nc \\
\hline
\end{tabular}

SRepiph: mean epiphytic species richness per plot; SRground: mean ground species richness within $1 \mathrm{~m}$ of the trunk per plot; SRglob: mean epiphytic and ground species richness per plot. ABground= total ground bryophyte abundance at plot level, i.e. within $1 \mathrm{~m}$ of the trunks of three trees par plot; $\mathrm{N}=$ maximum measured ground bryophyte abundance at plot level $\left(45,000 \mathrm{~cm}^{2}\right)$ 
Table SM 10. Best model for epiphytic and ground bryophyte species richness response variable at tree level.

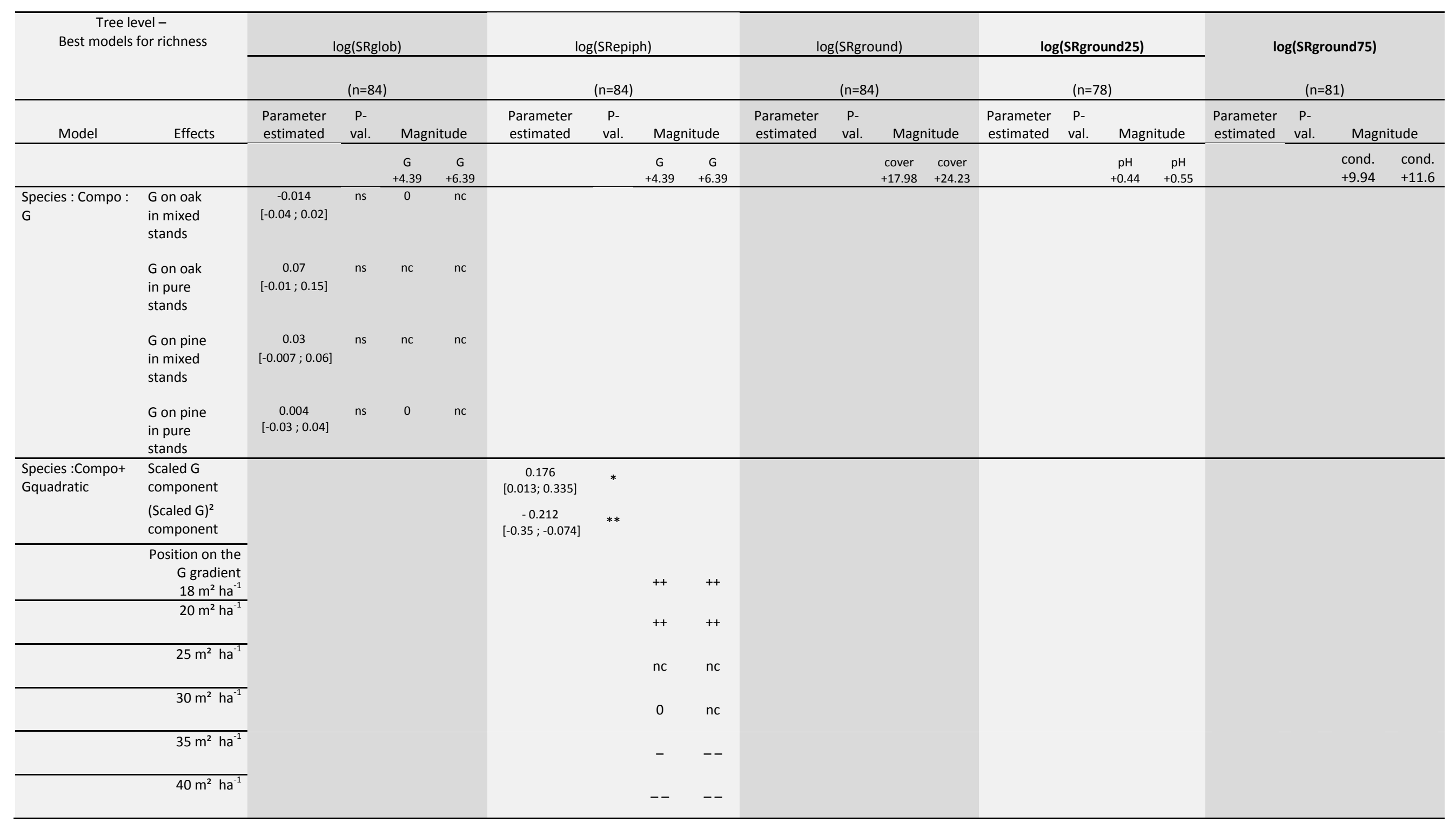




\begin{tabular}{|c|c|c|c|c|c|c|c|c|c|c|c|c|c|}
\hline $\begin{array}{l}\text { Species :Compo+ } \\
\text { RecInterfGlob }\end{array}$ & $\begin{array}{l}\text { Interfering } \\
\text { plant cover }\end{array}$ & $\begin{array}{c}-3.4 .10^{-5}[- \\
0.006 ; 0.006]\end{array}$ & ns & 0 & 0 & & & & & & & & \\
\hline $\begin{array}{l}\text { Species :Compo+ } \\
\text { OM_pH }\end{array}$ & $\begin{array}{l}\text { Organo- } \\
\text { mineral } \\
\text { horizon } \mathrm{pH}\end{array}$ & & & & & $\begin{array}{c}-0.22[-0.46 \\
; 0.017]\end{array}$ & ns & 0 & 0 & & & & \\
\hline $\begin{array}{l}\text { Species } \\
+ \text { Throughfall } \\
\text { conductivity }\end{array}$ & $\begin{array}{l}\text { Throughfall } \\
\text { conductivity }\end{array}$ & & & & & & & & & $\begin{array}{c}-0.022[- \\
0.04 ;- \\
0.008)\end{array}$ & $* *$ & $\mathrm{nc}$ & - \\
\hline
\end{tabular}

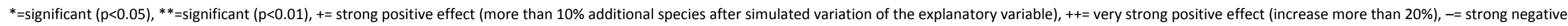
effect (fall of more than $10 \%),--=$ very strong negative effect (fall of more than $20 \%$ in species). G= basal area $\left(\mathrm{m}^{2} \mathrm{ha}^{-1}\right.$ ), throughfall conductivity in $\mu \mathrm{S} \mathrm{cm}^{-1}$, Interfering plant cover in \%. 
Table SM 11. Best model for ground and epiphytic species abundance at tree level.

\begin{tabular}{|c|c|c|c|c|c|c|c|c|c|c|c|c|c|c|c|c|c|}
\hline \multirow{2}{*}{\multicolumn{2}{|c|}{ Tree level - Best models for abundance }} & \multirow{2}{*}{\multicolumn{4}{|c|}{$\begin{array}{c}\text { logit(ABground/Nmax) } \\
(n=84) \\
\end{array}$}} & \multirow{2}{*}{\multicolumn{4}{|c|}{$\begin{array}{c}\text { logit(ABground25/Nmax) } \\
(\mathrm{n}=84) \\
\end{array}$}} & \multirow{2}{*}{\multicolumn{4}{|c|}{$\begin{array}{c}\text { logit(ABground75/Nmax) } \\
(n=84) \\
\end{array}$}} & \multirow{2}{*}{\multicolumn{4}{|c|}{$\begin{array}{l}\text { logit(ABepiph) } \\
(\mathrm{n}=84)\end{array}$}} \\
\hline & & & & & & & & & & & & & & & & & \\
\hline \multirow[t]{2}{*}{ Model } & \multirow[t]{2}{*}{ Effects } & \multirow[t]{2}{*}{$\begin{array}{l}\text { Parameter } \\
\text { estimated }\end{array}$} & \multirow[t]{2}{*}{ P-val. } & \multicolumn{2}{|c|}{ Magnitude } & \multirow[t]{2}{*}{$\begin{array}{l}\text { Parameter } \\
\text { estimated }\end{array}$} & \multirow[t]{2}{*}{ P-val. } & \multicolumn{2}{|c|}{ Magnitude } & \multirow[t]{2}{*}{$\begin{array}{l}\text { Parameter } \\
\text { estimated }\end{array}$} & \multirow[t]{2}{*}{ P-val. } & \multicolumn{2}{|c|}{ Magnitude } & \multirow[t]{2}{*}{$\begin{array}{l}\text { Parameter } \\
\text { estimated }\end{array}$} & \multirow[t]{2}{*}{ P-val. } & \multicolumn{2}{|c|}{ Magnitude } \\
\hline & & & & $\begin{array}{c}G \\
+4.39\end{array}$ & $\begin{array}{c}G \\
+6.39\end{array}$ & & & $\begin{array}{c}G \\
+4.39\end{array}$ & $\begin{array}{c}G \\
+6.39\end{array}$ & & & $\begin{array}{c}\mathrm{pH} \\
+0.278\end{array}$ & $\begin{array}{c}\mathrm{pH} \\
+0.311\end{array}$ & & & $\begin{array}{c}G \\
+4.39\end{array}$ & $\begin{array}{c}G \\
+6.39\end{array}$ \\
\hline \multirow[t]{4}{*}{ Species : Compo : G } & G on oak in mixed stands & $\begin{array}{c}-0.09 \\
{[-0.69 ; 0.49]}\end{array}$ & ns & nc & $\mathrm{nc}$ & & & & & & & & & & & & \\
\hline & G on oak in pure stands & $\begin{array}{c}-0.06 \\
{[-1.21 ; 1.16]}\end{array}$ & ns & nc & $\mathrm{nc}$ & & & & & & & & & & & & \\
\hline & $\mathrm{G}$ on pine in mixed stands & $\begin{array}{c}0.15 \\
{[-0.42 ; 0.74]}\end{array}$ & ns & nc & $\mathrm{nc}$ & & & & & & & & & & & & \\
\hline & $\mathrm{G}$ on pine in pure stands & $\begin{array}{c}0.59 \\
{[0.07 ; 1.12]}\end{array}$ & * & ++ & ++ & & & & & & & & & & & & \\
\hline Species + G & scaled G & & & & & & & & & & & & & $\begin{array}{c}0.26 \\
{[0.01 ; 0.52]}\end{array}$ & $*$ & $\mathrm{nc}$ & $\begin{array}{l}\mathrm{nc} \\
(+)\end{array}$ \\
\hline \multirow[t]{2}{*}{ Species : G } & scaled G on oak & & & & & $\begin{array}{c}-0.28 \\
{[-0.62 ; 0.07]}\end{array}$ & ns & $\mathrm{nc}$ & $\mathrm{nc}$ & & & & & & & & \\
\hline & scaled $\mathrm{G}$ on pine & & & & & $\begin{array}{c}0.2 \\
{[-0.2 ; 0.58]}\end{array}$ & ns & $\mathrm{nc}$ & $\mathrm{nc}$ & & & & & & & & \\
\hline $\begin{array}{l}\text { Species: Compo } \\
+ \text { February } \\
\text { throughfall pH }\end{array}$ & centered Feb. throughfall pH & & & & & & & & & $\begin{array}{c}2.2 \\
{[1.4 ; 3.1]}\end{array}$ & ** & ++ & ++ & & & & \\
\hline
\end{tabular}

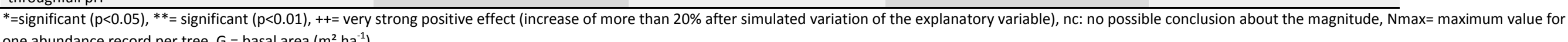
one abundance record per tree, $\mathrm{G}=$ basal area $\left(\mathrm{m}^{2} \mathrm{ha}^{-1}\right)$. 
Table SM 12. Best models for bryophyte richness and abundance at plot level

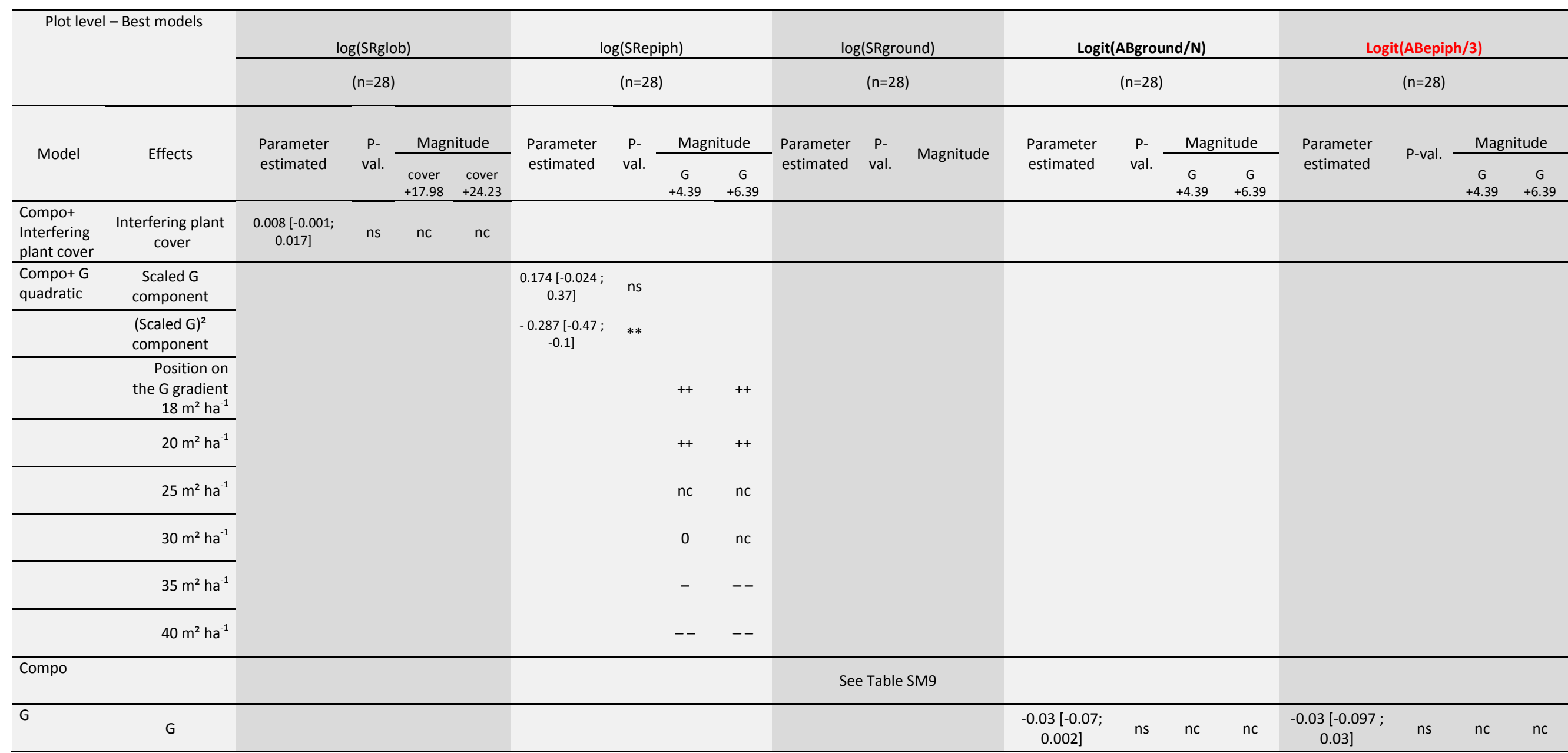

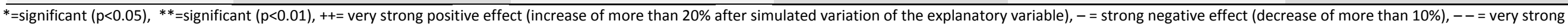
negative effect (decrease of more than $20 \%$ ), nc: no possible conclusion about the magnitude, $\mathrm{N}=$ maximum value for one abundance record per plot, $\mathrm{G}=$ basal area $\left(\mathrm{m}^{2}\right.$ ha $\left.{ }^{-1}\right)$, Interfering plant cover in $\%$. 
Table SM 13. Marginalized DIC values for models at plot level. The first row gives the marginalized DIC for the main stand composition model. Following rows concern exploratory models. For each response variable in a column, the best model corresponds to the lowest DIC value (grayed cells)

\begin{tabular}{llllll}
\hline & $\begin{array}{l}\text { SRglob } \\
(\mathrm{n}=28)\end{array}$ & $\begin{array}{l}\text { SRepiph } \\
(\mathrm{n}=28)\end{array}$ & $\begin{array}{l}\text { SRground } \\
(\mathrm{n}=28)\end{array}$ & $\begin{array}{l}\text { ABground } \\
(\mathrm{n}=28)\end{array}$ & $\begin{array}{l}\text { ABepiph } \\
(\mathrm{n}=\mathbf{2 8})\end{array}$ \\
\hline Stand_composition & 136.0504 & 117.2316 & $\mathbf{1 2 8 . 5 9 5}$ & $\mathbf{5 1 5 . 9 0 1 2}$ & $\mathbf{2 1 1 . 3 3 1 7}$ \\
\hline $\mathrm{G}$ & 167.6226 & 143.0606 & 153.2769 & $\mathbf{5 1 4 . 3 3 8 6}$ & $\mathbf{1 4 9 . 3 2 3 4}$ \\
\hline $\mathrm{G}+\mathrm{G}^{\wedge} 2$ & 170.5247 & 142.3934 & 153.7258 & 516.5306 & $\mathbf{1 5 4 . 8 3 5}$ \\
\hline Stand Composition : G & 139.2621 & 122.8585 & 133.8167 & 522.9837 & 212.3769 \\
\hline Stand Composition : $\left(\mathbf{G}+\mathrm{G}^{\wedge} 2\right)$ & 141.4208 & $\mathbf{1 1 6 . 3 0 8 9}$ & 137.1419 & $\mathbf{5 1 5 . 6 3 5 5}$ & 221.2377 \\
\hline Stand_composition + G & 138.7728 & 120.0632 & 132.8068 & 516.3748 & 231.1198 \\
\hline Stand_composition $+\mathrm{G}+\mathrm{G}^{\wedge} 2$ & 137.0047 & $\mathbf{1 0 9 . 3 2 1 2}$ & 132.2244 & 517.3257 & 233.0303 \\
\hline Stand_composition + Rec_Interf_Glob & $\mathbf{1 3 3 . 1 9 7 6}$ & $\mathbf{1 1 6 . 6 5 7 4}$ & 130.3806 & 517.9365 & $\mathbf{1 5 7 . 8 6 7 8}$ \\
\hline Rec_Interf_Glob & 154.0383 & 132.7376 & 139.401 & 518.2489 & 228.7067 \\
\hline
\end{tabular}

